\title{
Uptodate on GH/IGF-1 axis actions
}

\author{
Roberto Baldelli1 \\ Francesca Rota ${ }^{1}$ \\ Gianluca Aimaretti ${ }^{2}$ \\ Diego Ferone ${ }^{3}$ \\ Giovanni Vitale ${ }^{4}$ \\ Luigi Di Luigi ${ }^{5}$ \\ Agnese Barnabei ${ }^{1}$ \\ Paolo Marzullo 2 \\ Paola Razzore 6 \\ Andrea M. Isidori ${ }^{7}$ \\ Carolina Di Somma ${ }^{8}$ \\ Antonio Bianchi ${ }^{9}$ \\ Maurizio Poggi10 \\ Marialuisa Appetecchia1 \\ Andrea Lenzi ${ }^{7}$ \\ Annamaria Colao ${ }^{8}$ \\ Ezio Ghigo ${ }^{11}$
}

1 Endocrinology Unit, "Regina Elena" National Cancer Institute, Rome, Italy

2 Endocrinology, Department of Translational Medicine, University Piemonte Orientale "A. Avogadro", Alessandria, Italy

3 Endocrinology Unit, Department of Internal Medicine and Medical Specialties \& Center of Excellence for Biomedical Research, IRCCS AOU San Martino-IST, University of Genoa, Italy

4 Department of Clinical Sciences and Community Health, University of Milan, Istituto Auxologico Italiano IRCCS, Italy

5 Unit of Endocrinology, Department of Health Sciences, University "Foro Italico", Rome, Italy

6 Endocrinology, AO Ordine Mauriziano, Turin, Italy

7 Endocrinology and Food and Science Section, "Sapienza" University of Rome, Italy

8 Department of Molecular and Clinical Endocrinology and Oncology, University of Naples "Federico II", Naples, Italy

9 Division of Endocrinology, School of Medicine, Catholic University of Sacred Heart, Rome, Italy

${ }^{10}$ Division of Endocrinology, "Sapienza" University of Rome, Italy

${ }^{11}$ Department of Medical Sciences, Division of Endocrinology, Diabetology and Metabolism, University of Turin, Italy

Address for correspondence:

Roberto Baldelli

Endocrinology Unit, Regina Elena

National Cancer Institute

Via Elio Chianesi, 53

00144 Rome, Italy

E-mail: baldelli@ifo.it

\begin{abstract}
Summary
In December 2010, a workshop was held at "Regina Elena" National Cancer Institute in Rome, Italy, to develop an update on GH/IGF-1 system. The workshop was supported by NoGeRo group and was sponsored by SIE Lazio (Società Italiana di Endocrinologia-Lazio Regional Section) and AME Lazio (Associazione Medici Endocrinologi-Lazio Regional Section). Invited participants included italian endocrinologists skilled in the field of $\mathrm{GH}$ and IGF-I system both in basic and clinical research. In the following two years an extensive review has been structured summarizing the most important points achieved in the discussions during the workshop.
\end{abstract}

KEY WORDS: GH, IGF-1.

Introduction

\section{GH/IGF-I axis}

The GH/IGF-I system comprises of several proteins controlling growth, metabolism and senescence. Once thought to act predominantly through direct effects, it is now clear that the GH/IGF-I system can influence numerous cellular processes via indirect effects on the signaling machinery. From a hierarchical point of view, many growth-promoting actions of this system imply an adequate secretion of $\mathrm{GH}$, a 191 aminoacid single chain polypeptide hormone with 2 disulphide bridges originating from somato (mammo) troph cells located in the lateral sections of the pituitary, where $\mathrm{GH}$ is stored in granules of 350-500 nm (1). Five homologous genes exist in the GH locus, a $66 \mathrm{~kb}$ region of DNA located in chromosome 17q22-q24. In the circulation, the prevalent $\mathrm{GH}$ isoform is of $22 \mathrm{kDa}(\sim 73 \%)$, while less prevalent is the $20 \mathrm{kDa}$ isoform $(\sim 16 \%)$ as well as alternative isoforms ( 10\%). Spontaneous GH secretion is typically pulsatile and peaks every 60-90 min. It increases during the sleep, particularly during the stage 3-4. GH secretion is high in the fetal stage, decreases in the neonatal stage, then spontaneous peaks are more frequent and intense in pediatric age. Subsequently, it is calculated that $\mathrm{GH}$ production is $100 \mathrm{mcg} / 24 \mathrm{hr}$ in the prepuberal stage, $700 \mathrm{mcg} / 24 \mathrm{hr}$ in adolescents and $400 \mathrm{mcg} / 24 \mathrm{hr}$ in adults. Elderly individuals harbor the lowest levels of $\mathrm{GH}$ and this condition has been termed somatopause. $\mathrm{GH}$ yields a $20-40$ min half-life if administered intravenously and a 12-24 hr half-life if administered intramuscularly. The regulatory mechanisms of $\mathrm{GH}$ secretion are sexually dimorphic, with men having 
larger nocturnal GH pulses and relatively smaller pulses at daytime compared to women, who show more continuous and uniform GH pulses. On the other hand, rh-IGF-I administration causes a more potent feedback on spontaneous and $\mathrm{GHRH}$-induced $\mathrm{GH}$ secretion in men than women, suggesting in the latter a stronger intervention on hypothalamic GHRH on the negative regulation of GH secretion (2). Several factors are known to influence the secretion of $\mathrm{GH}$. Among these, $\mathrm{GHRH}$ and somatostatin act as the chief neuroendocrine stimulator and suppressor, respectively, while the physiological role of ghrelin on $\mathrm{GH}$ stimulation needs further elucidation. It is worth mentioning the stimulatory effect of exercise, stress, aminoacids, muscarinic cholinergic and alpha-adrenergic tone, glucocorticoids (acutely), opioid peptides, L-arginine and hypoglycaemia. Oppositely, beta-adrenergic tone, glucocorticoids (chronically), obesity, malnutrition and hyperglycaemia all are negative regulators of $\mathrm{GH}$ secretion (3). The peripheral effects of $\mathrm{GH}$ include multiple actions on: bone metabolism, by increasing osteoclast differentiation and activity, osteoblast activity, bone mass and endochondral bone formation; linear growth, where $\mathrm{GH}$ promotes epiphyseal growth (this is also known as the "dual effector" theory), stimulates the differentiation of prechondrocytes and the local expression of IGF-I, which then increases clonal expansion of chondrocytes; muscle mass, through effects on amino acid transport, nitrogen retention, lean tissue formation and energy expenditure; adipose tissue, by increased lipolysis, inhibited lipoprotein lipase, stimulated hormone sensitive lipase, decreased glucose transport, decreased lipogenesis (4). The cellular actions of GH are mediated by a transmembrane receptor (GHR) of 620 aminoacids that belongs to the type-1 cytokine receptor family; the extracellular domain also works as the circulating $\mathrm{GH}$ binding protein, and retains diagnostic significance in the $\mathrm{GH}$-resistance setting (5). In the cell, GH action is mediated by multiple signaling cascades, the most relevant of which is the JAK-STAT pathway (6). Mutations in the GHR gene provoke a condition of GH resistance: over 600 mutations have been identified and all lead to Laron's syndrome, a condition of IGF-I deficiency, short stature and typical somatic features. In addition to the previous, it has become clear that postreceptor mutations, particularly those involving Stat 5-b, can also cause $\mathrm{GH}$ resistance. In such settings, treatment with rh-IGF-I is approved as the only effective therapeutic tool to compensate for the hormone loss (6). Once known as the peripheral effector of $\mathrm{GH}$, it is now evident that IGF-I not only is GH-dependently and -independently involved in controlling growth but it also controls cell proliferation. IGF-I is a basic polypeptide of 70 amino acids (M.W. $7600 \mathrm{~d}$ ), formed by two chains linked by a connecting peptide. The liver produces $>$ $80 \%$ of the circulating peptide, however IGF-I is expressed and synthesized in multiple tissues where it acts to govern local cellularity and metabolism via autocrine and paracrine actions. It circulates as a single non-glycosylated chain with two disulfide bridges, and a $50 \%$ amino acid sequence homology to insulin explains its ability to bind to insulin receptors and insulin-IGF-1 hybrid receptors, thereby also acting at the metabolic level with insulin-like properties. IGF-I shares $~ 60 \%$ sequence homology to IGF-II. IGF-I levels are influenced by multiple factors, with $\mathrm{GH}$ being the most relevant. Among the other contributors, also important are the genetic environment, nutrional state, sex hormones, IGFBPs, insulin, thyroid hormones, cortisol, immune system and catabolic states (7). IGF-I levels increase gradually from childhood and reach their peak concentration at puberty, then they decrease gradually. In the circulation, IGF-I is associated with ALS and IGFBP-3 in a $\sim 150 \mathrm{kDa}$ complex that works as a reservoir of IGF-I and contributes to regulate its bioactivity and half-life. All components of this ternary complex are regulated by GH. Moreover, IGF-I and IGFBP-3 can form binary complexes, that are active locally. As mentioned above, recent evidences indicate that $\mathrm{GH}$ and IGF-I roles on growth are partly independent. It has been estimated that growth processes in mammals depend for $\sim 34 \%$ on a their combined action, for $\sim 14 \%$ on $\mathrm{GH}$ alone, for $\sim 35 \%$ on IGF-I alone and for $\sim 17 \%$ on other factors (8). Recent data further suggest that IGF-I can amplify the metabolic actions of $\mathrm{GH}$ and contrast its deleterious effects on lipolysis, gluconeogenesis and insulin-resistance (9). Indeed, many cellular actions of IGF-I are proliferative and antiapoptotic in several organs and apparatuses. One central player in the prevention of cell death is the IGF-I receptor (IGF-IR). Transduction of signals through this receptor leads to multiple series of intracellular phosphorylation events and the activation of several signaling pathways. The IGF-IR consists of two disulphide-linked $a \beta$ heterodimers and it is structurally similar to the insulin receptor (10). Both IGF-I and IGF-II bind the IGF-I receptor with high affinity and insulin binds with lower affinity. Upon ligand binding, the receptor has tyrosine kinase activity resulting in autophosphorylation, recruitment of docking proteins such as IRS-1 and subsequent stimulation of many signal transduction pathways, including Ras/MAP (mitogenactivated protein) kinase, PI3 kinase/PKB (protein kinase B) Akt and PI3 kinase/mTOR. These pathways convey mitogenic and metabolic signals and certain effects of insulin and IGFs can be limited by drugs or nutritional conditions that alter AMPK (AMP-activated protein kinase) signalling or mTOR signaling. Mechanisms of IGF system signaling that prevent cell death continue to be identified, suggesting that cells have alternative ways to avert death signals in addition to primary protective pathways. While the IGF-I receptor is virtually ubiquitous in humans, its density appears to differ from one tissue to another. However, IGF-IR activation by IGF-I delivered to the cell by endocrine, autocrine or paracrine modalities, is accompanied with relevant actions on immediate early gene expression, stimulation of myogenesis, apoptosis, cell cycle progression, immune response modulation, induction of enzymes involved in steroidogenesis, and sex steroid production (11). Actions on cell survival involve increased activity of antiapoptotic factors (through modulation of p53, NF$\mathrm{kB}, \mathrm{Bcl}-2$ expression) and inhibition of proapoptotic factors (through modulation of caspases and Bad) (10). The IGF-II/mannose 6-phosphate (M6P) receptor is 
structurally distinct from IGF-I and insulin receptors, it binds IGF-II with high affinity, IGF-I with far lower affinity and does not bind insulin. Its major IGF-related role appears to be IGF-II internalisation and clearance. A soluble form of this receptor which lacks the transmembrane and intracellular domains is found in the circulation. It should be mentioned that IGF-I genotyping has revealed a role for IGF-I mutations in cardiovascular disease, while mutations in the IGF-IR gene may retard intrauterine and subsequent growth in humans (12). The GH/IGF system is thus relevant in many physiological and pathophysiological conditions. The direct involvement of IGF-I in human diseases like GH-related disorders, cancer, atherosclerosis, diabetes, osteoporosis and neuromuscular disorders has prompted extensive research for therapeutic purposes. A better understanding of the system may enable to elaborate on ligand- and tissue-specific IGF-based therapies without interfering with physiological processes. Additionally, their role in the diagnosis and monitoring of diseases should be better clarified in the near future.

\section{IGF-binding proteins (IGFBPs)}

The IGF system, besides the two growth factors IGFI and IGF-II, the cell surface receptors, IGF-IR and IGF-IIR, comprises six specific high-affinity binding proteins (IGFBP-1 to IGFBP-6), as well as the IGFBP proteases, that regulate and propagate IGF actions in several tissues (13). Hepatic IGF-I circulates almost entirely (>99\%) bound to IGFBPs. IGFBP-3, a major IGFBP type in circulation, binds 75 to $90 \%$ of circulating IGF-I in a large ternary complex consisting of IGFBP-3, acid-labile subunit (ALS), and IGF (150 kDa). It is still debated whether IGFBP-3 in the liver is positively regulated upon $\mathrm{GH}$ stimulation or regulation of circulating IGFBP-3 in human subjects is due to increased formation of the ternary complex induced by $\mathrm{GH}(14,15)$. ALS is produced in the liver as a direct effect of GH. The ALS stabilizes the IGF-IGFBP-3 complex, reduces the passage of IGF-I to the extravascular compartment, and extends its half-life (13). More recently it has become clear that IGFBPs 1-6 have intrinsic biological activity (IGF/IGF-IR-independent actions) in addition to their actions to bind IGFs and sequester the active hormone. In particular, IGF/IGF-IRindependent actions of IGFBP-3 (antiproliferative and proapoptotic effects) seem to contribute in improving the pathophysiology of a variety of human diseases, such as cancer, diabetes, and malnutrition (16). Nine other forms of IGFBPs, which have low affinity for IGFs, have been identified due to their high homology in gene sequences with those of IGFBP 1-6 (17). These carrier proteins, whose role is currently under study, were grouped in a family defined as IGFBP related proteins (IGFBP-RP) (17). The binary complexes of $40-50 \mathrm{kDa}$, carrying $20-30 \%$ of IGF-I and II, are composed primarily of IGFBP-2. Plasma concentrations of IGFBP range from $5-50 \mathrm{ng} / \mathrm{ml}$ of IGFBP- 1 and $100-400 \mathrm{ng} / \mathrm{ml}$ of IGFBP-2 to $2-4 \mathrm{mg} / \mathrm{ml}$ of IGFBP-3, confirming the greater significance as carrier protein in circulation if this latter BP (17). Although the mech- anisms by which IGF complexes becomes available for binding with receptors in tissues are not yet fully understood, several studies have highlighted the existence of plasma and tissue specific proteases for IGFBPs, able to facilitate the process of dissociation from IGFBPs $(13,17)$. Several proteases specific for each IGFBP have been identified so far. Among these, metallo-proteases degrading IGFBP-3 are the best characterized, and are often serine proteases metal- and calcium-dependent (PSA, $\mathrm{Y}$-NGF, plasmin metallo-proteases MMP-1, -2 and -3 are part of this group). Beside the key role in growth and differentiation, there is now compelling evidence to suggest that members of the IGFBP family play important roles in metabolic homeostasis. For example, IGFBP-1 concentrations fluctuate inversely in response to changes in plasma insulin levels, implicating IGFBP-1 in glucoregulation, and fasting levels of IGFBP-1 predict insulin sensitivity at the population level, whereas IGFBP-2 concentrations reflect long-term insulin sensitivity and are reduced in the presence of obesity (18). Accumulating evidence indicates that abnormalities of IGF-I and IGFBP-1 occur in insulin-resistant states and may be significant in the pathophysiology of type 2 diabetes, as well as in the development of cardiovascular disease in metabolic disorders, including diabetes and obesity (19). These evidences are promising for future therapeutic strategies, because, based on the potential vasculoprotective effects of both IGF-I and IGFBP-1, the system represents an interesting and novel therapeutic target in the prevention of cardiovascular disease in type 2 diabetes. Moreover, progress on the metabolic-related function of IGFBPs has indicated the close relation between IGFBPs and the components of the metabolic syndrome. Indeed, abnormal expression of IGFBP has been detected in various states of the metabolic disorders, suggesting that it could be also used as a convenient and sensitive marker of insulin resistance, identification of insulin-resistant individuals at high cardiovascular risk, and may be an earlier marker of the metabolic syndrome (20). Bone metabolism represent another important target since the 6 IGFBPs are expressed by osteoblasts. However the principal actor in this setting seems IGFBP-2, which is required for normal bone formation in mice and seems also involved in bone remodeling (21). Conversely, the role of the other IGFBPs in bone homeostasis is still controversial, although it appears that their fundamental role is to bind and serve as transporters/regulators of IGF-I in this site as well $(21,22)$. Indeed, as already emphasized, IGFBPs can have both enhancing and inhibiting effects on IGF action, depending on context and posttranslational modifications. The IGF pathway has been shown to be activated in many cancer types (23). IGF binds to two types of receptors, IGF-IR and IGF-IIR, on cell membranes, and activates the tyrosine kinase pathway downstream. Binding of IGFBPs with IGF has been shown to either positively or negatively regulate the binding of IGFs to their receptors, thus directly affecting the IGF signaling pathways. However, several studies have found that IGFBPs 
may also function independently, interacting with proteins other than IGFs, may be cleaved, may bind to their own receptor on the membrane $(13,14)$. Importantly, there is increasing evidence that IGFBP-2, IGFBP-3, and IGFBP-5 are important players in the phenotypes of various cancers (23). Changes in the balance of the components of the IGF system may contribute to the progression of cancer $(23,24)$. The levels of IGFBPs have been associated with reduced risk for prostate, breast and other cancers $(23,24)$. Experimental studies have implicated high levels of IGF-I directly and IGFBP-3 inversely in prostate cancer growth, survival, and progression. In the European Prospective Investigation into Cancer and Nutrition (EPIC) study, high circulating IGF-1 concentration was positively associated with risk for prostate cancer (25). However, other evidences suggest a much weaker association of IGF-I with prostate cancer development and a stronger antagonistic association of IGFBP-3 with prostate cancer progression (26). Considering the clonal heterogeneity and unpredictable progression pattern of prostate cancer, the role of any single growth factor or its regulator, including IGFBP, as a single determining factor is limited. In breast tumors the abundance of IGFBPs relates to the estrogen receptor status and their production in the breast is controlled by hormones, principally estrogen and progesterone (27). However, also in this setting there conflicting observations between the effects of IGFBPs on the risk of cancer development, in particular IGFBP-3 (27). Indeed, the functional activity of IGFBPs can also be affected by proteolysis, phosphorylation and glycosylation and the implications of these determinants are still unclear so far. In general, the IGFs in certain tissues are present at levels far in excess of that required for maximal receptor stimulation, and the IGFBPs are critical regulators of their cellular actions. Beside this action, IGF-independent BPs effects on cell functions is still controversial. For example, again in breast, locally IGF bioactivity is influenced not only by tissue expression and regulation of IGFs, IGFBPs and IGFBP proteases, but also by other factors delivered from the circulation $(23,24)$. As prognostic values, only IGFBP-3 may serve as an important factor in evaluating cancer risk, in prognosis and, in the future, as a treatment as well. Although epidemiological studies vary in their conclusions about IGFBP-3 and reduced cancer risk, many population variables and assay problems may contribute to this lack of uniformity. Since IGFBP-3 is a highly effective proapoptotic factor in tumor cells by a variety of mechanisms, therapy directly with exogenous IGFBP-3 or indirectly with hormonal or other upregulators of IGFBP-3 may be an important mode of cancer therapy in the future (16). Recent evidence suggests that high serum IGFBP-2 could be a risk factor for low-grade prostate cancer (28).

\section{IGF-I system and life span}

Several evidences suggest that insulin/IGF-I signalling pathways play a pivotal role in the regulation of longevity (29-32). This hormonal system originated from a very early common ancestor. In animal models alterations of insulin/IGF-I signalling increase the life expectancy. In the nematode Caenorhabditis elegans, the down-regulation of the insulin/IGF-I pathway genes (DAF-2, AGE-1 and AKT) extend survival up to $300 \%$ (29). The link between reduced insulin/IGF signalling and longevity was subsequently confirmed in Drosophila melanogaster (33). The insulin/IGF-1 pathway became complicated with evolution. Mammals developed two well characterized hormonal systems: insulin and GH/IGF-1, with different metabolic and developmental functions. Rodents with reduced $\mathrm{GH}$ and/or IGF-1 signalling showed extended lifespan as compared to control siblings. Importantly, these genetic alterations can keep the animals healthy and protected from several age-related diseases (32, 34, 35). However, in many of these models the long-lived phenotype was exclusively observed for females. In humans there are several contradictory results on this topic (31). Bonafe et al. (36) reported that subjects carrying at least an A allele at IGF-I receptor locus (polymorphism G/A, codon 1013) have low levels of circulating IGF-I and are more represented among long-lived people. A reduced functionality of IGF-I signalling has been subsequently detected in other populations of elderly subjects and centenarians $(37,38)$. In addition, several epidemiological studies described a positive association between serum IGF-I levels and cancer incidence and mortality $(26,39-41)$. On the other hand, in the elderly population relative high circulating IGF-I levels have been associated with a decrease in cardiovascular morbidity and mortality (4244). Besides, Paolisso et al. (45) reported a decrease in serum IGF-I and an increase in IGF-I/IGF binding protein 3 (IGFBP-3) ratio in Italian centenarians compared with aged subjects (70-99 years). This observation indicates an increase of IGF-I bioavailability in centenarians. All these contradictory data are probably related to the complexity of metabolic pathways and the difficulties of evaluating IGF-I bioactivity in humans. Another limit observed in previous studies arises from the comparison of serum IGF-I levels between centenarians and a control group of younger subjects. This comparison induces a significant bias related to the age influence of IGF-I. In fact, IGF-I values rise from birth until puberty then decline with advancing age. Centenarians' offspring, meaning people who have at least one centenarian parent, result to be an emerging model of longevity without the disadvantages observed in the studies of centenarians. These subjects are old people (age range 65-85 years) with a more favourable aging process, when compared with age-matched controls who do not have long-lived parents, and with the following characteristics: a lower risk for all causes of death; a lower prevalence of cardiovascular diseases, stroke, diabetes and cancer; an increased age of onset of age-related diseases $(46,47)$. Interestingly, it is possible to compare centenarians' offspring with a demographically-matched control group (subjects matched for age, sex, ethnicity, parent year of birth, but born from non long-lived parents) 
thus avoiding cohort effects. Suh et al. (38) reported that female centenarians' offspring were smaller and displayed higher IGF-1 levels, indicative of IGF-1 insensitivity, compared with female controls. In addition, an overrepresentation of heterozygotes for mutations in the IGF-1 receptor gene, associated with IGF-1 insensitivity, was found among Ashkenazi Jewish centenarians. Therefore, the down regulation of IGF-1 system observed in centenarians and centenarians' offspring might significantly extend the lifespan by minimising the risk of cancer in these subjects, indicating that IGF-1 pathway is an evolutionarily conserved mechanism of longevity from yeast to humans.

\section{Growth hormone and insulin-like growth factor axis and sport}

Many relationships between the growth hormone-insulin-like growth factor (GH-IGF) axis [e.g. hormones (GHRH, Somatostatin, Ghrelin, GH, IGF-1, etc.), GH and IGF binding proteins (GHBP, IGFBPs), receptors, proteases, etc.], physical exercise and sport exist. Particularly, we shortly highlight: a) the main characteristics of the GH-IGF-1 axis adaptive responses to acute and chronic exercise-related stress, b) the worldwide use of GH and IGF-1 as performance enhancing substances (i.e. as doping) by healthy athletes, and the anti-doping challenges to detect their abuse, and c) the problem of sport eligibility/participation and therapy in athletes affected by diseases associated to GH and/or IGF-1 hypoor hyper-secretion/function.

\section{GH/IGF-1 responses to physical exercise}

Depending on exercise characteristics, acute sub-maximal and sprint exercises represent a powerful stimulus to human $\mathrm{GH}$ secretion, and all molecular $\mathrm{GH}$ isoforms increase few minutes after starting a single bout of exercise (48-50). Whereas few studies exist, chronic exercise (e.g. training) has been shown to increase $\mathrm{GH}$ pulsatility and/or nocturnal secretion both in healthy athletes trained above lactate threshold (51) or in obese subjects affected by metabolic syndrome (52). $\mathrm{GH}$ exerts its specific acute effects directly during and immediately after exercise, but also IGF-1 seems to contribute in mediating the GH signals. In fact, conflicting studies have shown an increase, a decrease or no modifications of serum total or free IGF-1 concentration after acute or chronic exercise (53). These observed discrepancies are probably related to differences in experimental protocols and to the numerous factors influencing the hormones response to exercise (see after). The mechanisms regulating $\mathrm{GH}$ response to exercise are yet to be fully elucidated. As also reported in excellent reviews $(48,49)$, different mechanisms have been proposed to explain the origin of the stimulus for $\mathrm{GH}$ response to exercise (e.g. increased blood lactate or hydrogen ion concentration, oxygen demand/availability ratio, afferent signals from muscle metabolic receptors, proprioceptive mechanisms, adrenergic system, changes in core temperature). At hypothalamus-pituitary level, the reported stimuli may influence $\mathrm{GH}$ secretion throughout the combination of release of $\mathrm{GHRH}$, withdrawal of somatostatin and release of a GH releasing peptide (GHRP), such as the putative endogenous GHRP-like ligand Ghrelin. It has been hypothesized that low intensity exercises may induce moderate $\mathrm{GH}$ responses through activation of the central cholinergic system, resulting in a reduction in somatostatin release, whereas higher exercise intensities, once hypothalamic somatostatinergic tone is suppressed, further increase $\mathrm{GH}$ release by increasing $\mathrm{GHRH}$ secretion. The role of the inhibition of somatostatinergic tone in increasing $\mathrm{GH}$ secretion after exercise-related stress in humans has been also demonstrated by evaluating the $\mathrm{GH}$ response to exercise following pre-treatments with the somatostatin analogue octreotide (54) and with pyridostigmine $(55,56)$. In addition, the administration of GHRH at the start of an incremental exercise until exhaustion has been shown to have an additive effect on the $\mathrm{GH}$ response to exercise, and the co-administration of GHRH and GHRP-2 at the start of exercise further potentiated $\mathrm{GH}$ release (57), as did the only administration of GHRP-2 before exercise (58). The characteristics of GH and IGF-1 responses to physical exercise are related and differently influenced by exercise characteristics (e.g. type, intensity and duration, previous training, number and frequency of exercise bouts, muscles involved, time of the day), individual factors (e.g. genetic factors, individual responsiveness, gender, age, fitness status, nutrition), diseases (e.g. GH-deficit, obesity, etc.) and iatrogenic factors (e.g. supplements, doping substances, not prohibited drugs) $(49,59,60)$. The biological effects of GH and IGF-1 during and after exercise are related to specific modifications of respective peripheral pathways in different tissues, and to exercise related modifications of the other substances involved in the GH-IGF axis physiology (e.g. mainly IGFBP-1 and IGF$\mathrm{BP}-3$, etc.) $(53,61)$. The specific role of $\mathrm{GH}-\mathrm{IGF}$ axis in exercise physiology has not been completely evaluated but many of the $\mathrm{GH}$ and IGF-1 related cellular, metabolic and cardiovascular effects (e.g. increased cardiac contractility, stroke volume, lipolysis, free fatty acids availability, uptake and oxidation, fat sensitivity to catecholamines, protein synthesis, sweat secretion, cell proliferation, erythropoiesis, etc.) are of great usefulness in the physiological body's adaptation during and after exercise (i.e. during recovery) (48). Even if many relationships exist we still have to clarify the exact role of the GH-IGF axis in exercise physiology, particularly when local GH-IGF pathways in different tissues are concerned, and the possible positive and/or negative effects of physical exercise-related stress on such hormonal pathways in different physiological (e.g. puberty, aging) or pathological conditions (e.g. GHdeficit, metabolic diseases, osteoporosis).

\section{Doping with GH/IGF-1}

GH and IGF-1, and all their respective secretagogues (e.g. GHRH, Ghrelin), are considered prohibited substances by the World Anti-Doping Agency (WADA) 
(see at http://www.wada-ama.org/en/World-Anti-Doping-Program/Sports-and-Anti-Doping-Organizations/International-Standards/Prohibited-List/) and by all National Anti-Doping Organizations (NADO). GH is one of the most abused prohibited substances between athletes and body builders. However, although GH abuse may increase lean body mass and may improve anaerobic exercise capacity in healthy individuals (62), existing scientific evidences do not support a possible role of $\mathrm{GH}$ in enhancing sport performances in athletes $(63,64)$. In our opinion, a great problem in evaluating the effects of GH/IGF-1 abuse on athletic performance during official experimental protocols (i.e. authorized by an ethical committee) is related to the impossibility to reproduce in healthy athletes the same type of $\mathrm{GH}$ abuse really performed by humans. In fact, to enhance each specific type of performance in different sports/physical activities athletes and body builders usually assume together different anabolic substances (e.g. androgenic anabolic steroids, $\mathrm{GH}$, insulin), and other prohibited (e.g. central nervous system stimulants, glucocorticosteroids, etc.) and not prohibited drugs and supplements (e.g. thyroxine, PDE5 inhibitors, amino acids, etc.), often at very high supra-physiological doses and with empirical regimens of administration and associations. Besides the possible GH/IGF-1 abuse related effects and consequences on performance and health (e.g. antibodies anti-GH, nausea, headache, hyperglycaemia, diabetes, hypertension, fluid retention, arthralgia, gigantism, acromegaly, cancer, etc.) (64), it is of great difficulty to know all the possible effects, adverse events and health risks related to multi-substances abuses. In anti-doping, many factors can influence the GH/IGF-1 abuse detection (e.g. similarity between endogenous and exogenous hormones, selection of "reliable markers", type of assays, normal ranges in athletes, used biological fluids, anti-doping timing, assay's reliability), consequently, it is still difficult to find the best and optimal method for detecting doping with such substances $(65,66)$. Whereas no definitive technologies to detect IGF-1 abuse in athletes exist, two methods are actually used to detect GH abuse: 1) the isoforms method, that was developed to distinguish between the proportions of different human GH isoforms in physiological conditions (i.e. natural mixture of 22-KDa and non-22-KDa isoforms) and those found after recombinant human $\mathrm{GH}$ (rhGH: only 22$\mathrm{KDa}$ isoforms) injection (i.e. increase of 22-KDa and decrease of non-22-KDa isoforms), 2) the markers method, that is based on a mathematical calculation performed by using the serum concentrations of specific GH-dependent biological markers (e.g. IGF-1, propeptide of type III pro-collagen) with respect to control values $(65,66)$. Even if these two methods have a reasonable sensitivity and specificity, some concerns still exist and some new proposed markers (e.g. c-terminal cross-linked telopeptide of type I collagen, haemoglobin a-chain, etc.) or methods (e.g. surface plasmon resonance, mass spectrometry, etc.) to detect $\mathrm{GH}$ abuse in athletes should be further evaluated (66-68).

\section{Sport participation in athletes with GH/IGF-1 dis- eases}

Due to the biological effects of $\mathrm{GH}$ and IGF-1 in the mechanisms of response to exercise-related stress and on body tissues involved in sport adaptation (e.g. heart, muscles, liver, etc.), sport participation is considered not physiological and not safe in athletes affected by diseases associated to $\mathrm{GH}$ and/or IGF-1 deficit or increase, particularly if other hormones deficit (e.g. pituitary adenoma) or serious complications are present. When indicated, athletes affected by GH/IGF-1 deficit or excess had to start the specific treatment before starting a competitive sport activity. According to WADA (see at http://www.wada-ama.org/ en/Science-Medicine/TUE/) and to respective NA$\mathrm{DO} /$ Federations regulations, in competitive athletes with $\mathrm{GH} / \mathrm{IGF}-1$ deficit it is mandatory to obtain a Therapeutic Use Exemption certificate by the respective NADO or International Sport Federations before starting $\mathrm{GH}$ or IGF-1 treatment at substitutive doses and after sport participation. In that Countries were sport eligibility is granted by an external Authority an in deep and sport-specific pre-participation screening is mandatory/indicated (i.e. in Italy is mandatory to obtain the sport eligibility certificate by authorized sport physicians) before starting/re-starting sport participation in treated athletes with GH/IGF-1 diseases (69). Due to rhGH pharmacokinetic, in young and adult athletes affected by $\mathrm{GH}$-deficit further studies are warranted to identify the optimal rhGH administration regimen (i.e. morning or evening administration? single or multiple daily doses?) to guarantee a physiological competition by reproducing also during and immediately after each exercise/competition all the effects of $\mathrm{GH}$ on muscles, heart and metabolisms.

\section{GH-IGF-I axis: drug interferences}

In normal cells, insulin-like growth factors (IGF-I and IGF-II) and their six high-affinity binding proteins (IGFBPs) contribute to regulation of cell growth, metabolism, and death. IGFBPs modulate IGF activity by reducing IGF bioavailability to bind to the cell surface IGF receptors (IGFRs). Balance between growth factors and IGFBPs is modulated by specific IGFBP proteases. Recent data suggest that IGFBPs may also exert significant IGF-independent actions. Free, unbound IGF-I exerts major actions in carbohydrate, lipid, and protein metabolism through activation of the IGF-IRs. This primary receptor for IGF-I is a heterotetrameric tyrosine kinase membrane receptor. It displays selective, but not exclusively, binding affinity for IGF-I, because IGF-IR can bind both IGF-II and insulin with less affinity ligand. IGF-IR undergoes autophosphorylation and conformational changes that trigger an intracellular signaling cascade through the insulin receptor substrates 1 to 4 (IRS1-IRS4) and Src homology and collagen. These molecules activate the two main downstream signals of IGF-IR: the mitogenactivated protein kinase and phosphatidylinositol 3-kinase/Akt pathways. IGF-IIR can bind these growth 
factors but acts as a signal decoy and does not transduce the signal intracellularly. The last two members of the insulin receptor family are the insulin receptor (IR) and, especially in tumor cells, the hybrid receptors IGF-IR/IR. The hybrid receptors also signal after binding IGF-I or IGF-II, similar to the function of IGF-IR. In normal conditions, both the IGF-IR and insulin receptor (IR) signaling pathways have overlapping functions and complement each other. Differences in the metabolism, availability of the ligand, receptor expression, or pharmacologic manipulations may change the equilibrium in signaling between those two systems. The development of cancer is determined by a combination of environmental factors and genetic predisposition. Recent evidence suggests that dietary and related factors such as physical activity and body size may contribute to malignancy progression through their effects on the serum concentration of IGF-I and its binding proteins. The molecular mechanisms by which the GH-IGF-IGFBP axis is deregulated in malignant cells is complex, and abnormalities at each of the levels have been described in different tumors. Overexpression of the growth factors (IGF-I or IGF-II) or the receptor, by either gene amplification, overexpression of convertases or transcription factors, have been observed in different tumors. The polymorphisms in the genes along the GH1/IGF-1 axis could influence hormone levels and cancer risk, especially breast cancer $(70,71)$. Also, post-traslational modifications of the IGF-IR by glycosylation and the potential co-activation of the insulin pathway through their co-expression or through hybrid receptors (IGF-IR/IR) are further potential mechanisms associated to cancer. Modification of the concentration of IGF-BPs (especially IGFBP-1, IGFBP-3, and IGFBP-5) or of the insulin receptor can modify the overall activation of the pathway. Finally, lost of IGF-IIR, a negative regulator of IGF signaling that works by as a decoy by binding the growth factor, could drive cells into an IGF-IR - dependent growth. Expression of the IGF-IR has been reported in a broad panel of tumor types. Being so ubiquitous, IGF-IR could play different roles in different tumor types or cellular contexts. Some tumors may be dependent on IGF-IR signaling for survival, and its inhibition might trigger apoptosis and a subsequent cytotoxic effect. This could probably be the mechanism behind the dramatic responses observed in tumors like Ewing sarcomas. Some other tumors may rely on IGF-IR for proliferation, like neuroendocrine tumors. Inhibiting IGF-R will produce a cell cycle arrest and, thus, a cytostatic effect. Other tumors may have IGF-IR overexpression as a survival mechanism against cytotoxic insults, and combining chemotherapy with an IGF-IR inhibitor may overcome this mechanism of resistance. This could be the case of the observed synergy between chemotherapy or radiotherapy and IGF-IR inhibition, as well as with other targeted therapies like trastuzumab, EGFR inhibitors, and hormone therapies. Recently, discoveries of GH-IGF-IGFBP axis's actions in cancer allowed the design of specific inhibitors that may interrupt the signaling associated with this axis. The ability to manipulate these pathways hold not only significant ther- apeutic implications but also increase the chance of deeper insight about the role of the axis in carcinogenesis and metastasis. About 25 molecules are currently at different stages of development, including both tyrosine kinase inhibitors and monoclonal antibodies $(72,73)$. Further approaches are being developed, including peptides, proteins, or antisense oligonucleotides that antagonize IGF-IR. However, these agents have not reached the clinic. Because of compensatory crosstalk between IGF-1R and IR, dual IGF-1R and IR tyrosine kinase inhibitors may have superior anti-tumor activity compared to anti-IGF-1R specific antibodies (74). Hyperglycemia, mild skin toxicities (rash, flushing, pruritus, acne), and fatigue as common toxicities of these drugs. Other observed toxicities, like reduction in CD4+ lymphocytes, thrombocytopenia, and transaminitis, do not seem to be related with the mechanism of action but with specific antibodies. Hyperglycemia seems to be frequent (around 20\%) but tolerable, mild to moderate (grades 1 and 2), reversible, and manageable with an oral hypoglycemic drug, such as sulfonylureas. Although still premature, these promising data, consistent with the effect seen with chemotherapy, justify its investigation in cancer types like prostate cancer, advanced head and neck cancer, and locally advanced pancreatic cancer where radiation therapy forms part of the main initial treatment. The estrogen pathway and its relation with IGF has been explored in tamoxifen-resistant breast cancer models. This resistance is in part mediated by IGF-IR/mitogenactivated protein (MAP) kinase signaling pathway and cSrc seems to be one of the critical elements. Thus, the small molecule XL-228, tyrosine kinase inhibitor of both Src and IGF-TK seems a good candidate for development in this setting. Clinical experiments demonstrated no significant modifications in GH response to GHRH after acute or chronic treatment with tamoxifen compared with the basal test. On the contrary, chronic tamoxifen treatment induced a significant decrease in serum IGF-I levels. These data confirmed the inhibitory effect of tamoxifen on IGF-I production, but seem to exclude the possibility that this effect may be due to an inhibition of GH secretion (75). Results of translational research aimed to identify biomarkers associated with sensitivity to IGF-1R/IR inhibitors remains the only way to select the right patients who would benefit of the appropriate single-agent therapy, or the most suitable combination therapy. Mutations in downstream signaling pathways such as PIK3CA, the expression of IGF axis ligand-receptor pairs, markers associated with epithelial-mesenchimal transition, free IGF1 ligand levels, and a host of multi-gene biomarkers are the most promising molecular features that may predict sensitivity to IGF-1R/IR inhibitors.

\section{GH/IGF-1 axis and oncological risk}

Many experimental in vitro models evidenciated the link between $\mathrm{GH}$ and IGF system with cancerogenesis processes. In 1950 (76) it was reported that high-dose treatment with extracted $\mathrm{GH}$ was able to induce development of lungs, adrenals, ovaries, and breast neopla- 
sia in female rats. Studies with transgenic mice confirmed the role of $\mathrm{GH}$ in animal oncogenesis (77); $\mathrm{GH}$ was found to stimulate the cellular proliferation of different cancer cell lines, including human leukemic lymphocytes and murine erythroleukemic cells. Another important aspect confirming the effect of GH on carcinogenesis is the GH synthesis in a different number of extrapituitary organs including both normal and neoplastic mammary tissues so a possible local paracrine/autocrine effects independent of or additional to endocrinemediated IGF-I action could be supposed (78). Furthermore in prostate cancer cell lines, $\mathrm{GH}$ is able to increase cell proliferation probably due to the coexpression of pituitary $\mathrm{GH}$ as well as GH-R mRNA isoforms; so an autocrine-paracrine pathway seems to be able to stimulate prostate growth $(79,80)$. Unlike $\mathrm{GH}$, the IGF system modulates the oncogenesis process at different steps (81); once quiescent cells are made competent and the stimulation with IGF-I is sufficient to complete the cell cycle, promote cell proliferation and arrest apoptosis, both in normal and cancer cell lines $(82,83)$. The effects of IGF-I stimulation is related to the density and functionality of the IGF-IR and this is fundamental for the IGF-Imediated proliferation (82). A confirmation of IGF-I/IGFIR involvement in oncogenesis has been shown in vitro experiments where knockout of IGF-IR gene was capable of decreasing cell proliferation and increasing apoptosis. Moreover the IGF-I/IGF-IR system seems to further influence tumoral progression promoting different mechanisms such as adhesion and migration of cells, angiogenesis within neoplastic tissues and surrounding areas $(82,84)$.

In vitro, IGF-I does not seem to promote cellular transformation, rather seems to stimulate proliferation of transformed cell clones and the growth of pre existing tumor tissues. In fact liver-specific IGF-I-deficient mice treated with chronic IGF-I administration are characterized by the presence of processes of growth and metastatic proliferation of colon adenocarcinomas transplanted cells (85). As for GH, also for IGF-1, endocrine and autocrine/paracrine effects in a number of tissues and cell systems are reported. Regulation of cancer growth through an IGF-I/IGF-IR-mediated autocrine/ paracrine loop has been reported by the demonstration of IGF-IR mRNA expression in colon carcinoma, more abundant than IGF-I mRNA expression (86), and predominates in samples from colon tumor vs the adjacent normal mucosa, a condition suggestive of paracrine/autocrine modulation (87). In situ hybridization studies have evidenciated that IGF-I is expressed in the stromal cells and very rarely in the epithelium of breast cancer while IGF-IR has been found on neoplastic breast epithelial cells suggesting the presence of a paracrine interaction (88). IGF-I levels are significantly higher in women with breast cancer (89) and in men with prostate tumors (90), respect to normal population. In the European Prospective Investigation into Cancer and Nutrition (EPIC) study, high circulating IGF-1 concentration was positively associated with risk for prostate cancer (25). In a study of survey on 152 cases of prostate cancers, among nearly 15,000 men subjected, Chan et al. (91) provided evidence of a 2.4-fold greater cancer risk asso- ciated with IGF-I levels in the upper quartile of the normal range, compared with patients whose IGF-I values were in the lower quartile. Another study conducted by Hankinson et al. (92) reported that the relative risk of breast cancer in premenopausal women with IGF-I levels in the upper tertile of the normal range was 2.3 times higher than in patients with IGF-I in the lower tertile. In particular women below age $50 \mathrm{yr}$, the highest IGF-I tertile was associated with an increase in breast cancer risk to 4.6 and, after inclusion of IGFBP-3 levels in the multivariate analysis, to 7.3 (92). Ma et al. (93) analyzed IGF-I and IGFBP-3 levels in 193 men diagnosed with colorectal cancer over a 12-yr follow-up, and reported that the relative risk in men having IGF-I levels in the top quintile was 2.5 times greater than in those whose IGFI was at the bottom quintile. Inversely, the relative risk calculated by IGFBP-3 quintiles was 0.28 for top vs bottom quintile. Another important aspect suggesting the link between the GH/IGF system and human cancers is the demonstration that $\mathrm{GHRH}$-antagonists, GH-antagonist, and somatostatin analogs elicit antineoplastic activity by altering the GH/IGF-I axis at the pituitary level or by inhibiting autocrine/paracrine activity of $\mathrm{GHRH}, \mathrm{GH}$, and IGFs (94-97). Moreover, preliminary findings have indicated that the $\mathrm{GH}$-antagonist decreased proliferation, stimulated apoptosis, and reduced metastatic spreading of MCF-7 breast cancer cells (78).

\section{GH/IGF-I axis and heart}

$\mathrm{GH}$ and IGF-I are potent cardiotrophic factors and their involvement is similarly crucial in cardiac diseases. Their role will be here examined relatively to three main settings: the process of cardiac regeneration, the chronic consequences of altered GH secretion and cardiovascular data from the general population. Analysis of these topics will then try to provide reasonable argumentations for their therapeutic use in heart disorders.

\section{Cardiac regeneration mediated by GH/IGF-I}

Apoptotic death and necrosis are relevant events in a number of cardiac diseases. Experimental cardiac infarction is associated with an upregulated autocrine IGF-I system which is capable of stimulating DNA replication and mitotic division in viable cardiac myocytes, as confirmed by enhanced proliferating cell nuclear antigen (PCNA) message and transcript (98). IGF-I directly promotes survival and proliferation of resident cardiac stem cells, with consequent improved myocardial regeneration after myocardial infarction (99). This antiapoptotic effect also comprises of indirect actions, as mesenchymal stem cells overexpressing IGF-1 can attenuate infarct by stimulating VEGF expression, which then modulates neovascularization and myogenesis (100). In humans, rhGH increases IGF-I levels in parallel with circulating endothelial progenitor cells (EPC, a sensible predictor of cardiovascular outcomes), these latter exhibiting improved colony forming and migratory capacity, enhanced incorporation into tube-like structures and augmented 
eNOS expression (101). IGF-I treatment of human EPCs improved function and attenuated cellular senescence, further suggesting a role for IGF-1 in aging EPC. Based on the previous, local IGF-I delivery and genetic manipulation of IGF-I expression seem effective tools to obtain a modulation of cardiac regeneration. These forms of treatment could be repeated over time to reduce progressively tissue scarring and expand the working myocardium.

\section{Cardiovascular consequences of GH and IGF-I ex- cess}

Cardiomegaly is a hallmark of visceromegaly associated with acromegaly. It is traditionally thought to progress toward cardiac failure unless $\mathrm{GH}$-excess is removed. Interindividual differences in cardiac involvement likely depend on varying age, familiarity, duration of disease, resistant arterial hypertension (up to $50 \%$ of patients are hypertensive), longstanding diabetes mellitus (about 1/3 patients are glucose-intolerant and just as many are diabetic), ventilatory disorders (obstructive sleep apnea affects $\sim 80 \%$ of cases), arrhythmia (present in up to $30-40 \%$ of patients, being mainly supraventricular and largely conditioned by cardiac hypertrophy and sleep apnea), as well as cardiac valve disease (mitral and aortic regurgitation affects $75 \%$ of patients, mostly those with cardiac hypertrophy). The interplay of altered glucose homeostasis, hypertension and aging explain a stepwise increase in the prevalence of cardiac hypertrophy, diastolic and systolic dysfunction (102). Two main goals should be, intuitively, pursued to modify long-term cardiovascular consequences of acromegaly. First, it is crucial to achieve complete control of GH hypersecretion by neurosurgical cure or pharmacological management. Somatostatin analogs are a valid tool to achieve control of cardiovascular complications of acromegaly and recent studies displayed similar global effects of octreotide LAR and lanreotide autogel on left ventricle mass, diastolic and systolic function. The $\mathrm{GH}$-antagonist pegvisomant has also been found to yield significant cardioprotective results in a 18-month analysis (103). Treatment with pegvisomant reduces heart rate and improves rhythm abnormalities in acromegaly (104). Secondly, effective complementary treatment of comorbidities is essential: antihypertensive agents, hypolipemic and antidiabetic compounds, as well as noninvasive mechanical ventilation are all instrumental to achieve full control of cardiopulmonary complications of acromegaly. In this scenario, literature data linking heart valve disease to the use of dopamine-agonist warrant appropriate surveillance in acromegalic patients treated with high-dose cabergoline.

\section{Cardiovascular effects of GH deficiency (GHD)}

It is known that hypopituitary patients with GHD bear an increased risk for coronary artery disease and impaired cardiac function leading to a 2-fold greater cardiovascular mortality than the general population.
Childhood- and adulthood-onset GHD reduces left ventricle mass and diameter proportionately to the duration of GHD or to IGF-I levels. This is concomitant to an impairment of cardiac performance at peak exercise and abnormal diastolic filling (105). In large cohorts, cardiac dysfunction occurs proportionately to the severity of GHD, with systolic and diastolic abnormalities affecting $45-78 \%$ of GHD patients (106). The so-called hypokinetic syndrome of GHD coexists with other key risk factors, which include visceral adiposity, insulin resistance, atherosclerosis and hypercoagulability. Importantly, patients with GHD following cure of acromegaly or Cushing's disease are more prone to develop hypertension, diabetes mellitus and stroke than those with GHD from any other cause (107). The influence of obesity is equally important as seen in studies on adults with Prader-Willi Syndrome, a monogenic disorder associated with morbid obesity and GHD (108). In populations with classical GHD, GH therapy produces positive cardiac effects depending on patient's medical history, multiplicity of pituitary deficiencies and comorbidities. A metanalysis reported that $\mathrm{GH}$ treatment was associated with a significant increase in LV mass $(+10.8 \mathrm{~g})$, septum thickness $(+0.28$ $\mathrm{mm})$, LV posterior wall $(0.98 \mathrm{~mm})$, end-diastole diameter $(+1.34 \mathrm{~mm})$, and stroke volume $(+10.3 \mathrm{~mL})$, while overall effect sizes were not significant for most indices of diastole (109).

\section{General population studies}

Most studies have been so far published on IGF-I, with a role for $\mathrm{GH}$ necessitating further evidences. IGF-I is thought to influence cardiovascular disease (CVD) through complex mechanisms, yet results are contrasting. Following a Danish study on ischemic heart disease (IHD) that reported a significant association between the 15-yr risk and low IGF-I and high IGFBP3 levels (44), the Rancho Bernardo Study confirmed the inverse association between IGF-I levels and IHD mortality in subjects aged over 50 yrs but no association with non-IHD cardiovascular (CVD) mortality (110). A key study by Lamberts' group found IGF-I bioactivity assessed by kinase receptor activation (but not total or free IGF-I levels) to be associated with extended survival and reduced CVD risk in elderly men followed up for $>8$ yrs (111). At variance with these data, the NHANES and the Third NHANES Mortality Study carried out in 6226 adults aged $20 \mathrm{yr}$ or older failed to confirm these associations (112). Moreover, there is evidence that a reduced GH-IGF1 signaling increases lifespan in animal models, while a blunted activity in the IGF-I pathway also seems to be associated with longevity in humans (38). In line with this, a population-based study of 642 individuals aged $50-89$ yrs found that IGF-I levels in the fourth quartile were independently associated with $>5$-fold increased risk of cardiac heart failure (113). The association between IGF-I and mortality is, therefore, not linear and divergences may result from unadjusted confounding phenomena, assay drawbacks or differences in demographic data. These discrepancies are partly recon- 
ciled by recent evidence showing that both elevated and reduced IGF-I levels may double the risk of CVD mortality, thus that a U-shaped relationship links IGFI to CVD mortality (114).

\section{Cardiovascular effects of GH or IGF-I administration}

In the last 15 years, debated evidence has accumulated on GH or IGF-I utility as therapeutic agents in cardiac failure. Chronic heart failure (CHF) is featured by (primary or secondary) structural and functional cardiac abnormalities that coexist with altered vascular reactivity, this latter being primarily due to endothelium-dependent defects and loss of bioactive endothelial nitric oxide. Increased peripheral vascular resistance further aggravates LV failure. Importantly, GH improves eNOS activity and increases NO availability via IGF-I. Following the description of a GHD patient improving dilated cardiomyopathy with rh-GH treatment (115), several subsequent studies have suggested that rhGH may increase LVEF and decrease systemic vascular resistance in CHF patients. These effects show a rapid onset and depend not exclusively on the improved endothelium-dependent vasodilatation, but also on modifications in loading conditions, myocardial contractility and cardiac morphology. A meta-analysis showed significant overall effects of rhGH on LV walls, end-diastole volume, ejection fraction, systemic vascular resistance, NYHA class, exercise duration and $\mathrm{VO}_{2}$ max in CHF patients (116). Oppositely, double-blind placebo-controlled studies on rhGH effects failed to show direct effects on cardiac function or structure in CHF patients of different aetiologies (117). Therefore the results are conflicting (118). Scant but relevant are the findings on the therapeutic usefulness of IGF-I. Acute infusion of rhIGF-I in healthy subjects increases cardiac output, heart rate and stroke volume significantly (119). The possibility that IGF-I may be beneficial in cardiac disorders has been explored in CHF patients, and rh-IGF-I yields positive effects on the cardiac index, stroke volume and peripheral resistance (120). However, long-term effects are unknown. It is also interesting to note that, recently, similar results on LVEF, LVM, and exercise capacity were reported after treatment with GH releasing hormone and ghrelin in patients with $\mathrm{CHF}$ (121).

\section{GH/IGF-I axis and glucose metabolism}

It is well known that diabetes and insulin resistance are the major determinant of metabolic syndrome involving in cardiovascular mortality $(122,123)$ and that alterations of the GH/IGF-I contribute in determining cardiovascular disease with increased risk for cardiovascular morbidity and mortality both in GH deficiency (GHD) and excess (103). The GHD mediated effects on the cardiovascular function are directly played on the heart and endothelium but also in indirectly manner by increasing all cardiovascular risk factors with particular role made by central adiposity, insulin resist- ance and finally by glycemic metabolic derangement and metabolic syndrome (124). Visceral obesity is a central feature of metabolic syndrome and furthermore is well known that obese subjects have a functional GH deficiency; in a recent paper Di Somma showed an higher prevalence of metabolic syndrome in GHD obese patient than GH sufficient obese patient suggesting a possible maladaptive role for functional GHD in obesity with increased metabolic risk factors in severe obesity independently from BMI per se (125). Epidemiological perspectives studies confirm the association between low IGF levels and all causes and cardiovascular disease mortality (110) and in prospective observational study IGF-I showed a significant inverse association with subsequent 2 -h glucose concentrations independently correlates of IGF-I and risk factors for glucose tolerance providing protective role for IGF-I against development of glucose intolerance (126). Furthermore in large epidemiological cohort study type 2 diabetes showed a curvilinear association with IGFI SDS (127) and in recent cross sectional epidemiological study IGFI is an independent predictor of diabetes (128). Many studies have confirmed that $\mathrm{GH}$ therapy in GHD patients reduce visceral fat, improves insulin sensitivity and atherosclerotic profile with in turn reduction in prevalence of cardiovascular risk factor and metabolic syndrome (129). High prevalence of metabolic syndrome in adult GHD patients (respectively $51.8 \%$ in USA and $28.6 \%$ in Europe) was recently reported in a large series without prevalence difference after $\mathrm{GH}$ replacement although baseline MetS status and obesity were strong predictors of Mets after $\mathrm{GH}$ treatment (130). Taking metabolic advantage from molecular analogy between insulin and IGFI some study demonstrated either an increase in insulin sensitivity and glycemic tolerance in type 2 diabetes with sever insulin resistance (131) or a reduction in insulin doses in type 1 diabetes using IGFI administration or equimolar IGFI-IGFBP3 complex $(132,133)$. In acromegalic patient a reduced life expectancy was reported reduced first due to cardiovascular disease (134) with hypertension and glucose intolerance as important independent contributory factors to the vascular morbidity associated with acromegaly (135). Retrospective comparative study reported a significant increase of cardiovascular risk factors in acromegalic patients matched for age and gender from general population with a prevalence of diabetes even 2.9 fold higher (136) while diabetes's prevalence in acromegaly ranges in different study from $19-56 \%$ (106). Although somatostatin and somatostatin analogues reduce insulin secretion a recent metaanalysis on somatostatin analogues on glucose homeostasis suggest that modifications of glucose homeostasis induce by SSA may have an overall minor clinical impact (137). Non detrimental SSA therapy's effect on glucose metabolism was confirmed in long term first line SSA therapy without any differences between SSA treated and surgically cured patients with increasing BMI as major predictor of deterioration of glucose tolerance (138). In patients with acromegaly receiving lanreotide as primary treatment only $17 \%$ had 
a worsening of glucose status $(60 \%$ had no change, $27 \%$ had an improvement) and deterioration was significantly associated with smaller $\mathrm{GH}$ decreases during primary lanreotide treatment (139). Only limited data on glucose metabolism during pasireotide (SOM 230) a new multireceptor ligand SSA analogue in acromegaly are now available with significative increase in HbA1c levels after 3 months's therapy (140) according with octreotide and lanreotide 6 and 12 months therapy 's studies (141). Data from pegvisomant (a new GH receptor antagonist) therapy in acromegaly demonstrate a significant reduction on $\mathrm{Hba1c}$ levels in diabetic and non diabetic patients with a correlation with IGFI reduction. Urbani $\mathrm{C}$ et al. found that the prevalence of diabetes or impaired glucose tolerance is higher during SSA than at diagnosis or during pegvisomant (142). Increase in insulin sensitivity after short term therapy (143) by a reduction in overnight endogenous glucose production related to related to reduced FFA levels was also demonstrated (144) according with data after acute pegvisomant administration using hyperinsulinemic euglycemic clamp in healthy subjects (145). Conflicting data from d3GH receptor polymorphism (a common polymorphic $\mathrm{GH}$ receptor variant) impact on metabolic phenotype are emerging in $\mathrm{GH}$ deficiency and acromegalic patients. In fact in GHD adults patients the presence of $d 3 G H$ receptor polymorphism may cause a major sensitivity to negative metabolic $\mathrm{GH}$ effect (146). In acromegalic patients was reported a slightly higher prevalence in diabetes mellitus in d3GHR acromegalic patient (147); but on the contrary Montefusco reported a decreased $\mathrm{BMI}$ with a preponderance of normal glucose tolerance between d3GHR patients in contrast to $\mathrm{fl} / \mathrm{flGHR}$ but similar prevalence of overt diabetes mellitus (148). Insulin resistance, impaired glucose tolerance and diabetes mellitus due to acromegaly disease generally improve with the GH/IGFI normalization but no comparative study are available on diabetes's best therapy and we have just suggestions pointed to oral secretagogue hypoglicemic agents and or insulin therapy, particularly new long acting insulin analogues when metabolic disease arise during SSA analogues therapy in responsive patients $(149,150)$ or Pegvisomant's use in somatostatin analogues resistant patients with coexistent diabetes mellitus (151).

\section{GH/IGF-1 axis and reproduction}

Growth hormone $(\mathrm{GH})$ is obligatory for growth and development, but it has also an important role in the reproductive process. It is required for sexual differentiation and pubertal maturation and it participates in gonadal steroidogenesis, gametogenesis and ovulation (152-154). The effects of GH are exerted at three levels: a permissive action on gonadotropins secretion and action, a peripheral direct, or IGF-1 mediated, effect on gonadal development, and a paracrine effect, by locally produced IGF-1 (155). Lobie et al. used immunohistochemistry to localize $\mathrm{GH}$ receptor and binding protein and found intense immunoreactivity in the male reproductive system, including Leydig and Sertoli cells, vas deferens, prostate, ductus epididymis and seminal vesicles (156). This finding suggested that $\mathrm{GH}$ might stimulate local IGF-1 production. This parallel what is seen in ovarian tissues, where several authors found a strongly GH-binding activity, GH receptor $(\mathrm{GH}-\mathrm{R})$ immunoreactivity and mRNA encoding GH-R (157). The need for local GH and IGF-1 production has been related to the presence of a haematogonadal barrier: even if the gonads are highly vascularized, some cells in the ovary and testis must remain physically separated from systemic circulation since might be antigenic. For this reason some $\mathrm{GH}$ actions might mediated by hormones locally produced. Indeed, the entire $\mathrm{GH}$ /placental lactogen (GH/PL) gene cluster (chromosome 17), comprising five highly related genes (GH-N, PL-L, PL-A, GH-V and PL-B), is transcribed in the human testes and ovary, with $\mathrm{GH}-\mathrm{V}$ (the $\mathrm{GH}$ variant) being the most active gene transcriptionally $(158,159)$. In summary, GH presents a large variety of biological actions on reproductive tissues and IGF-1 may mediate some, but not all, of these effects. Nevertheless, the clinical role of systemic and paracrine GH/IGF-1 axeses have seldom been explored. Early studies documented that $\mathrm{GH}$ is required for normal sexual maturation in mammals: Laron and others showed an association between isolated $\mathrm{GH}$ deficiency in boys and delayed puberty, with the frequent clinical observation of micropene $(160,161)$ or smaller testes. Later on, Laron also showed that in these patients the administration of $\mathrm{GH}$ restored normal pubertal development (162). GH has been also implicated in the development and function of wolffian duct-derived structures such as the prostate and seminal vesicles (163). Regarding female reproduction, it was suggested a role of $\mathrm{GH}$ as intraovarian modulator and, in a series of in vitro studies, it was found that incubation of granulosa cells with insulin and IGF-1 increased their responses to stimulation by FSH (164, 165). So the co-treatment with $\mathrm{GH}$ augmented the ovarian response to stimulation by gonadotrophins. Furthermore, some studies found that $\mathrm{GH}$ may stimulate particular follicle populations selectively and proliferation of luteinized granulosa cells via an $\mathrm{FSH}$ and IGF-1-independent mechanism (166-168). On the basis of these encouraging results and after demonstration in pubertal boys of a clear effect of $\mathrm{GH}$ on Leydig cell function and on pubertal maturation of the testis, it was suggested an additional role of $\mathrm{GH}$ in spermatogenesis. These studies were mainly performed in the

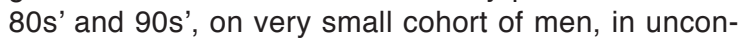
trolled studies. Nevertheless some of the findings are of interest showing a link between $\mathrm{GH}$ deficiency and some alterations of spermatogenesis. Shimonovitz et al. found more than $50 \%$ of azoospermic men, as compared to $18 \%$ of oligozoospermic men, showed subnormal $\mathrm{GH}$ response, as determined by the clonidine test. They proposed that GH may be involved in maturation arrests (169). GH effectively increases sperm concentration and/or motility in males resistant to other forms of fertility treatment in some, but not all, clinical studies with infertile patients (170-172). It has 
been proposed that $\mathrm{GH}$ affects sperm motility directly, or by actions mediated through Sertoli cells independently of IGF-1 (155). GH actions on spermatogenesis also can be mediated by influences on testosterone synthesis: $\mathrm{GH}$ therapy in $\mathrm{GH}$-deficient males augments the testosterone response to human chorionic gonadotropin, increases plasma estradiol levels, and increases the abundance of gonadotropic binding sites (171). The putative steroidogenic action of $\mathrm{GH}$ could involve hepatic/local IGF-1 modulation, although in vitro studies suggest an IGF-1-independent role for $\mathrm{GH}$ in Leydig cell function: Kanzaki and Morris have shown that $\mathrm{GH}$ increases androgen synthesis in rat progenitor Leydig cells. GH is thought to exert its effect at initial ratelimiting steps in the steroidogenic synthetic pathway, acting on synthesis of StAR protein (which regulates the translocation of cholesterol to the inner mitochondrial membrane) and $3 \beta$-hydroxysteroid dehydrogenase (3ßHSD) (which converts pregnenolone into progesterone) (173). Also reproductive dysfunctions in some women have been associated with partial $\mathrm{GH}$ deficiencies. Clinical studies have shown that $\mathrm{GH}$ therapy may be useful in some, but not all, infertile women $(174,175)$. GH administration to hypogonadotrophic anovulatory women significantly reduces the dosage and duration of hMG treatment required for ovulation induction and increases the percentage of successfully treated patients (175). GH therapy may also improve the success of in vitro fertilization techniques by enhancing the hyperovulatory response to hMG (176). Although the optimal therapeutic role of $\mathrm{GH}$ in induction or ovulation and spermatogenesis has yet to be totally defined, the reality of its interaction with gonadotrophins has clearly been demonstrated in vivo (177). More recently, the availability of human recombinant $\mathrm{GH}$, better definition of $\mathrm{GH}$ deficiency, allow a rigorous exploration the potential clinical use the strong connection between physiology of reproduction and growth and development. In addition, systemic and local GH seems to have a complementary autocrine or paracrine actions reflecting a 'fine-tuning' mechanism to regulate gonadal function (178).

\section{GH/ IGF-I and bone}

Growth hormone $(\mathrm{GH})$ and its mediator insulin-like growth factor I (IGF I) plays an important role in longitudinal bone growth and in acquisition of peak bone mass (PBM) during childhood and adolescence. Studies human and animal models have highlighted the integral effects of GH and IGF-I on skeletal development, linear growth, and the achievement of peak bone mineral density. The acquisition of peak bone mass, occurring at the end of skeletal maturation, is an important determinant of later development of osteoporosis and subsequent fracture risk (179). In addition, to the effects on longitudinal growth after the closure of epiphyseal growth plates, GH and IGF-I are anabolic hormones and have a key role in the regulation of bone modelling and remodelling (180). GH acts both inducing IGF-I in bone or playing direct effects on skeletal cells (Giustina A et al. 2008). The effects of $\mathrm{GH}$ and IGF on skeleton are modulated by interactions between circulating IGF-I and IGFBPs and the locally produced IGF-I and IGFBPs. In addition, the skeletal actions of GH/IGF-I axis are regulated by systemic hormones, such as sexual hormones and PTH (180). In particular, IGF-I and PTH have synergistic actions on bone and some effects of the anabolic actions of PTH are mediated by local production of IGF-I, as has been shown in vitro and in vivo studies both in animals and humans. On the other hand, PTH can induce skeletal IGF-I expression both in vitro and in vivo (181). Based on the aforementioned findings, it could be argued that diseases affecting GH/IGF-I axis induce skeletal abnormalities. In this section we will discuss skeletal abnormalities occurring in GHD and acromegaly, and the role of GH and IGF-I in the osteoporosis.

\section{GH deficiency and Bone}

GHD syndrome is mainly characterized by high fat mass with central adiposity and low lean body mass, dyslipidemia, hypertension, elevated inflammatory markers, insulin resistance, increased intima-media thickness, reduced exercise capacity, impaired quality of life (QoL), low bone mineral density (BMD) and increased risk of fractures (182). As proof of the state of low bone turnover, serum levels of osteocalcin and bone resorption markers are decreased and the same patients report a renal, skeletal, and intestinal cell insensitivity to PTH, leading to a mild state of PTH resistance and increased serum PTH levels (180). In the development of osteopenia a main role is played by GHD as suggested by the reduction of bone mineral density (BMD) both in patient with isolated GHD that in patient with multiple pituitary hormone deficiencies (MPDH) (183). In addition, only patients with very severe or severe GHD have a significant reduction of $\mathrm{BMD}$, associated with abnormalities of bone markers (183). This confirms the importance of GHD in pathogenesis of osteopenia in hypopituitaric patients (183). Associated other pituitary hormone deficits and/or replacement therapies have also been proved to be important factors in the pathogenesis of bone loss (180) as well as the age of onset of GHD and the age of the patients (180). Infact, in patients with childhood-onset GHD there is a marked reduction in vertebral BMD (Tscores often between 1 and 2; about one third of the patients have T-scores of 2.5 or less) (180). Other way, the vertebral T score results normal (1 or above) in patients with adult-onset GHD (180). The reduced bone mineral content and density in patients with childhood-onset GHD is probably due to the lack of attainment of bone mass during adolescence and the longer disease duration while the pathogenesis in patients with adult-onset GHD it is less clear $(180,183)$. The correction for height has demonstrated that short stature is less significant in the determination of a lower BMD observed in childhood-onset GHD, whereas changes in body composition may play a significant 
role (180). There is no definitive data demonstrating an increase in the risk of fractures in patient with decreased bone mass for untreated GHD. However, the risk of non-vertebral fractures (prevalently localized at the radius) has been found to be about 3 times more often in untreated GHD patients, suggesting a loss of cortical bone (180). As far as vertebral fractures, recent studies reported an increased incidence of vertebral deformities (180). Other pituitary hormone deficiencies or hormonal replacement therapy do not influence the prevalence of bone fractures while the degree of GHD affects this prevalence (180). In particular, in GHD patients, BMD does not correlate with the prevalence of fractures (180) as well as in other forms of secondary osteoporosis (180). On the other hand, these patients had an increased risk of falls for decreased muscular strength and impaired vision could be contributed to risk of fracture (180). For what concerns the GH replacement therapy it has been observed an initial reduction in BMD due to a stimulation of bone turnover by $\mathrm{GH}$ that leads to an increase in remodeling space (182). However long-term GH replacement is associated with an increase of bone mass (182). Jørgensen et al. found an increase of bone markers during the study and an increase in bone mineral content (BMC), BMD and bone mineral area (BMA) in the lumbar spine (L2-L4) and total body measurements after nine months of $\mathrm{GH}$ replacement therapy and in the femur (not BMA) measurements after a longer therapy. These different effects in the lumbar spine, total body and femur can be explained probably with the different actions of $\mathrm{GH}$ on cortical and trabecular bone. GH replacement therapy increases lumbar (L2-L4) spine and femur neck BMD in younger as well as elderly GHD patients (184). Effects of GHD on bone metabolism and the results after $\mathrm{GH}$ replacement therapy are influenced by the sex of patients, too. Many authors have put in evidence that after 18-24 months of GH therapy there was a small increase of BMD in male patients with adult- onset $\mathrm{GHD}$, instead there were not significant evidences of increase in female patient. In a recent study, a $2 \mathrm{yr} \mathrm{GH}$ replacement normalizes IGF-I levels, increases bone mass and improves bone turnover both in men and in women with GHD without any difference between the two groups, provided that the dose of GH was modulated on the basis of IGF-I levels. Women receiving oral estrogens should receive a $\mathrm{GH}$ dose approximately doubled, as compared to men and women not receiving oral estrogens, to achieve similar effects on bone density and turnover. In particular, GH replacement dose to be successful on bone mass and turnover depend on gender in hypopituitary patients aged below 50 yrs (185).

\section{GH excess and Bone}

Gigantism and acromegaly are conditions associated with elevated levels of GH and IGF-I. In these patients the body water and the lean body mass are increased and the body adiposity is decreased (179). As concern the bone metabolism, these patients have an increase of bone turnover, calcium kinetics and bone histomorphometry (180). Both bone formation and resorption are increased, but the increase of bone resorption markers is higher than the bone formation markers. These difference could be associated to the degree of bone loss observed. Moreover there is a correlation between serum GH and IGF-I levels with bone markers (180). In addition, active acromegaly is associated with increased serum concentrations of PTH, 1,25-dihydroxyvitamin D3, calcium, and phosphorus (180), probably due to the $\mathrm{GH}$ stimulation on parathyroid gland (180). The cortical and the trabecular bone have a different sensitivity to $\mathrm{GH}$ excess so the skeletal site play an impotant role in the determination of the effects of GH excess on BMD (180). In fact acromegalic patients have an increased in BMD at the lumbar spine which is rich in trabecular bone, whereas there is an increase in the BMD at the forearm where the cortical bone has a major representation (180). In spite of the variability of data on BMD in acromegaly, due to the different densitometry techniques, the results obtained with peripheral quantitative computerized tomography and bone biopsies have demonstrated different effect of the GH/IGF-I effects on the trabecular and cortical bone (180). In acromegaly other factors could influence bone BMD such as age, gender, and the presence or absence of hypogonadism (180). In fact, it has been observed that the decrease of vertebral BMD is correlated with the increase of the duration of the hypogonadism (180). Even if there is not a large number of studies about the risk of fractures in acromegaly (180) postmenopausal women with active acromegaly have a higher incidence of radiological vertebral deformities than non acromegalic postmenopausal women (186). This can be explained with an association between acromegaly and an increased risk of osteoporotic vertebral fractures (180, 187 ) which is correlated with the duration of active disease and the serum level of IGF-I, whereas there is no significant relationship between vertebral fractures and BMD values in acromegalic patients (180, 187). As concern the effects of acromegaly's treatment on bone metabolism, an improvement has been observed in fractures and BMD after surgical treatment (transphenoidal pituitary surgery) or pharmacological therapy. However data about treatment and his influence on bone are limited (180). Some authors have demonstrated that therapy with the $\mathrm{GH}$ antagonist pegvisomant, a selective antagonist of the GHR, which controls IGF-I secretion lead to a normalization of bone turnover (180). A reduction has been demonstrated in PTH target organ sensitivity and a reduced nocturnal rise in $\mathrm{PTH}$ after the normalization of GH/IGF-I levels (180). The hormonal control in postmenopausal women lead to a reduction of risk of radiological vertebral fractures than women with active disease. These improvement is not correlated with BMD value (180). In conclusion, the mechanisms underlying the metabolic bone disease of acromegaly are multifactorial and possibly include an increase in bone resorption secondary to IGF-I excess and to sex hormone deficiency. 


\section{Postmenopausal and senile osteoporosis}

The occurrence of postmenopausal osteoporosis is about $35 \%$ of white women and $19 \%$ of white elderly men (180). Among risk factors estrogen deficiency plays a main role both in postmenopausal osteoporosis and in possibly male osteoporosis (180). Secondary hyperparathyroidism, vitamin $D$ deficiency, decreased IGF-I levels and a large number of other factors could lead to the bone loss, probably due to decrease of osteoblastic functions in elderly population (180). A reduction of GH and IGF-I secretion, called "somatopause", has been demonstrated in advancing age. This event could be implicated in the pathogenesis of osteoporosis (180). In fact some studies have observed a reduction of serum IGF-I levels in postmenopausal women which is correlated with BMD. Moreover has been demonstrated that IGF-I promoter polymorphisms have been linked to bone mass (180). Both the serum IGF-I and the IGF-I contained in human cortical bone decrease with age (180). There are different evidences about the effects of rh-GH in postmenopausal female, males with idiopathic osteoporosis and elderly patients. In these patients has been observed an improvement of bone metabolism but the effect of rhGH on BMD is controversial (180). Some authors have observed a positive effect of rhGH treatment on increase in BMD in osteoporotic patients, other authors have demonstrated any benefic effects although an increase of serum IGF-I levels (180). In a recent meta-analysis has been observed that older people have not any improvement in bone metabolism due to rh-GH treatment. This probably can be explained by the lack of controlled trials and the heterogeneity of the subjects examined (180). Recent studies have demonstrated that treatment with an orally active GH secretagogue (MK677) combined with alendronate can determinate an improvement of BMD only at femoral neck in postmenopausal osteoporosis (180). Recombinant human IGF-I can influence bone metabolism in humans, but there is no skeletal specificity and potential side effects which would limit its possible use in osteoporosis (180).

\section{Obesity and GH/IGF-I axis}

It has been shown that nutritional state is an important factor involved in the control of Growth Hormone (GH) secretion. In human obesity, the GH/IGF-I axis is altered at different levels. Basal GH secretion is blunted, with reduced $\mathrm{GH}$ half-life, frequency of secretory episodes and daily production rate and it has been reported that an increase in each unit of BMI, at a given age, reduces the daily $\mathrm{GH}$ secretion by $6 \%$ (188). GH secretion is impaired in response to all stimuli acting at the hypothalamus and to direct stimulation by exogenous GHRH (Growth Hormone Releasing Hormone).The plasma levels of the high affinity GHBP (Growth Hormone Binding Protein) are increased, with a positive correlation between serum levels of this molecule and both BMI and percent body fat mass. The physiological significance of increased GHBP in obesity is unknown. Increased GHBP levels in obesity may serve to prolong the biological activity of $\mathrm{GH}$, however various studies showed that the clearance of $\mathrm{GH}$ is accelerated in obesity. Because circulating levels of GHBP reflect $\mathrm{GH}$ receptor density, an alternative explanation might be that the greater density of tissue receptors acts to sequester $\mathrm{GH}$ more avidly from the circulation, and this phenomenon might represent tissue adaptation to reduced $\mathrm{GH}$ output in obesity. The reduced $\mathrm{GH}$ response to $\mathrm{GHRH}$ in obese fasting patients seems to be caused by both central and peripheral factors. Among central factors, an impairment of endogenous GHRH tone or an augmentated somatostatin release has been hypotesized. It has been also suggested that the defect resides in the pituitary gland, with enhanced somatostatin release being responsible for the blunted $\mathrm{GH}$ response. However, many experimental evidences confirmed that both GHRH and somoatostatin release are normal in obesity and that there isn't a somatotrope cell insufficiency, since we observe a great $\mathrm{GHRH}$ and $\mathrm{GH}$-releasing peptide- 6 induced $\mathrm{GH}$ release in obese subjects (189). In obesity, GH secretion is blunted in response to other stimuli acting at the hypothalamus (insulin-induced hypoglycemia, arginine, galanin, L-dopa, clonidine) and the pharmacological manipulation of the central neurotransmitter systems are capable of modifying, but not completely restore, the response to these stimuli. Amongst the peripheral factors, the role of the increased bioavaibility of IGF-1, measured by IGF-1/IGFBP-3 ratio, and their possible increased negative feedback action on somatotroph cells has been underlined in some studies. However, in obesity, IGF-I plasmatic levels could be normal, low or high, despite high serum levels of the free fraction of IGF-I. Free IGF-I accounts for less than $1 \%$ of the total circulating amount of IGF-I and it is believed to be responsible for the bioactivity on target tissue. Two recent study $(190,191)$ indicated that free IGF-I are significant increased in overweight and obese patients; therefore, it seems not correct to define obesity a condition of $\mathrm{GH}$ resistence or insensitivity. Finally, according to the presence of increased levels of free IGF-I, in obesity IGFBP-1 (Insulin-like Growth Factor Binding Protein-1) and -BP-2 plasma levels are blunted, due to inhibition by insulin, which is generally increased in overweight subjects, whereas IGFBP-3 levels are normal or high. On the other hand, some authors have shown that low IGF-I levels are inversely correlated with abdominal obesity, a condition associated with higher serum concentrations of non-esterifed fatty acids (NEFA). The mechanism of this clinical evidence is not well known. We know that adipose tissue is a relevant source of proinflammatory cytokines and recent data suggest that inflammatory mediators may play a role in inducing reduced IGF-I bioactivity (192). The question of whether these mediators play a role in the IGF-I/IGF-binding protein system in obesity requires future study. Insulin and NEFA (or Free Fatty Acids, FFA) levels seem to be the most important peripheral factors involved in the blunted $\mathrm{GH}$ levels in obesity. Experimental and clinical data support the ex- 
istence of a negative feedback exerted by circulating insulin on $\mathrm{GH}$ secretion. Insulin is able to reduce $\mathrm{GH}$ release from rat pituitary in vitro, suggesting an IGF-Ilike effect, and it may be a major determinant in the suppression of $\mathrm{GH}$ output in the obese mouse by direct down-regulation of somatotrope function at pituitary level (193). Massive weight loss, inducing a decrease of insulin secretion, seems to be directly involved in the restore of a normal $24 \mathrm{~h} \mathrm{GH}$ profile (194). The surgical treatment of severe obesity, after stabilization of body weight, decreases body mass index (BMI) and fatt mass (FM) while preserving a normal lean body mass (LBM) as well as positively influencing insulin sensitivity. An interesting study in this field showed that in morbid obesity, after biliopancreatic diversion, the decrease in insulin secretion is the starting point for the changes in both body composition changes and somatotrope axis (195). In the same direction, recently, Cornford et al., showed a strong suppressed $\mathrm{GH}$ secretion in seven healthy non-obese men, after only 2 weeks of overeating and before any measurable weight gain; this phenomenon was accompanied only by a significant increase in insulin plasma levels, the likely mediator of the reduction in $\mathrm{GH}$ secretion (191). The direct infusion of FFA in normal weight subjects completely inhibits $\mathrm{GH}$ secretion. Several lines of experimental evidence indicate that high circulating FFA play an important role in the impairment of spontaneous and stimulated GH secretion in obesity, given the improvement of somatotropin release observed in obese patients after the administration of the antilipolytic agent acipimox (196). In such models such as PCO or old normal subjects, where the $\mathrm{GH}$ response to $\mathrm{GHRH}$ is similar to that in obese subjects, it has been shown how a pharmaceutical decrease in FFA levels can re-establish a normal GH response. However, the majority of these studies indicate that FFA reduction does not directly stimulate $\mathrm{GH}$ secretion, but augments the action of other stimuli at hypothalamus-pituitary level. The encouraging effects of $\mathrm{GH}$ in the treatment of Growth Hormone deficiency (GHD) syndrome have generated interest in the efficacy of using $\mathrm{GH}$ as anti-obesity drug. The rational of this treatment is firstly the observed lipolitic affect, especially on abdominal body fat, and the concomitant anabolic action related to growth of lean body mass. Conversely, the insulin-resistance, the impaired glucose metabolism, the onset of water retention, edema, carpal tunnel syndrome, arthralgia are the main doserelated side effects of $\mathrm{GH}$ therapy. The dose of $\mathrm{GH}$ more efficacious in obesity, and without side effects, was in the range of the current dose of GHD treatment, or slightly more low. The studies present in literature showed no significant effects of GH administration on BMI or LBM, independently from duration of treatment. In the majority of cases, a significant reduction in visceral adipose tissue, ranging from $5 \%$ to $34 \%$ was observed, mainly in the clinical trial of at least 12 weeks of duration (197). In comparison, therapeutic programs, with caloric restriction, diet and physical exercise achieve the same results regarding the fat mass. In conclusion, in obesity a clear de- crease in $\mathrm{GH}$ secretion with normal, high or low IGF-I, but high free IGF-I is observed. This condition is reversible and it seems to originate from peripheral factors, which alter hypothalamic-pituitary function. The restoration of normal GH/IGF-I axis function after weight loss suggests the presence of an acquired defect of metabolic origin. Clinical studies on the efficacy of rhGH as antiobesity drugs does haven't shown results in terms of weight loss significantly larger than those achievable with only diet-therapy. The observed effects of rhGH on body composition changes, with particular reference to reduction of abdominal and total fat mass are encouraging, but long term studies are nedeed.

\section{GH/IGF-I axis and Iymphohematopoietic system}

Important evidences show existence of a relationship between neuroendocrine and immune systems. Peptides exert effects in a cytokines like manner on immune, lymphoid and red blood cells. Production and differentiation of forerunners of red blood cells, myeloid and lymphoid cells are under cytokines, peptides and hormones control (198). In respect of hormones' actions, Growth hormone $(\mathrm{GH})$ and its proximal mediator insulin-like growth factor-I (IGF-I) have been shown to play an important role. GH acts directly through interaction on $\mathrm{GH}$ receptors (that is a cytokine receptor class 1) or indirectly through the IGF-I share. IGF-I shows both proliferative and anti apoptosis action (joint with receptors of Tyrosine kinase involved in the intracellular signalling of PI3K and anti apoptosis protein $\mathrm{Bcl} 2$ ). The presence of $\mathrm{GH}$ - and IGF-I- receptors on $B$ and $T$ lymphoid cells, monocytes macrophages, fibroblasts and neutrophylis suggest the possibility of an immune action in association with the principal endocrine activity (199). In the bone marrow and in the thymus IGF-I is capable to promote the survival of forerunners blood cells and to prevent apoptosis (through way of PI3K). GH deficit causes subclinical changes in the chemotaxis and in the phagocytosis of granulocytes and macrophages. Moreover patients affected by $\mathrm{GH}$ deficit have a reduction of $50 \%$ in the function of natural killer cells, CD3- and CD56+. GH deficiency is often associated with a higher frequency of infectious, autoimmunity disorders and allergy. Furthermore the activity of natural killer cells improves after three-months of replacement therapy with recombinant human $\mathrm{GH}$ ( $\mathrm{rhGH}$ ), and normalizes after six-nine month of $\mathrm{rh}-\mathrm{GH}$ replacement treatment. The functionality of phagocytes and neutrophilis improves after a long period of rh-GH therapy too. In humans the important role of GH/IGF-I axis has been underline, also, by in vivo study. Patients affected by $\mathrm{GH}$ deficiency show many immune changes like reduced functionality of NK, insufficient antibody synthesis, thymus atrophy and changes of immune response mediate by immune cells. $\mathrm{GH}$ deficit is associate with increased prevalence of atherosclerosis and, consequently, higher morbidity and mortality for cardiovascular events. Different trials have as- 
sessed a possible role of $\mathrm{GH}$ deficit and its recombinant replacement therapy on the monocytes's activation. In fact GH caused chemotaxis of monocytes, production of oxygen's radicals by macrophages and manage the TNFa expression. Monocytes play an important role in the development of the atherogenic plaque. In $\mathrm{GH}$ deficiency there is a damage in macrophages' functions: in bloodstream the capacity to adhere tightly to endothelial cells is increased by cytokines like IL-6 and TNF-a, markers of monocytes activation at the beginning of atherosclerosis' process. Others studies showed a relationship between $\mathrm{GH}$ deficit, anaemia and blood platelet reduction. GH replacement therapy improved concentration of haemoglobin, improved the myeloid activity and also increased secretion of cytokines like TNFa and IL-6. On the other side, in patients affected by high levels of $\mathrm{GH}$, like in acromegaly, a condition of clear polycythemia, reversible by surgical or medical therapy, could be observed. Lastly we can observe a reduction in the function of GH/IGF-I axis in elderly, catabolic conditions, important illness and where there is status of resistance. $\mathrm{GH}$ resistance syndrome is characterized by moderate increase of $\mathrm{GH}$ levels, high levels of IGFBP-1 and IGFBP-2 and reduction of IGF-I, IGF-II and IGFBP-3. Moreover there is a reduced capacity of IGFBP-3 to work and create complex (more of $90 \%$ of IGF-I in bloodstream is bound at complex with IGFBP3; IGF-I have anabolic effect and this one is higher when is bound in this complex) and so there is further reduction of IGF-I and IGF-II levels in bloodstream and changes in their biological activity. In elderly people changes of GH/IGF-I axis could be responsible for an increase in abdominal adiposity, a greater risk of cardiovascular mortality, and a depressed level of wellness. Immune senescence is associated with wasting thymus and reduction in oligoclonal T cells receptor. Older people are more susceptible of infections and show a reduction of immune answer to vaccines. In the future rhGH therapy could be a new chance to restore thymus functionality, to reduce age related changes and improve immune control against cancer and infections (199). Another important new therapeutic option for GH therapy could be in patients affected by HIV infection. GH/IGF-I axis functionality is important in protein synthesis and to preserve normal muscular mass. GH and IGF-I could increase the retention of nitrogenous and induce protein synthesis (200). Moreover, in some cases, GH/IGF-I function could have an important role in the nutritional status and body composition which are impaired in HIV infected patients. HIV infection produces an unspecific clinical status similar to many others endocrine and non endocrine illness while antiretroviral therapy causes endocrine malfunction too. Moreover in patients with AIDS it could be observed an important cachexia. AIDS-related cachexia is characterized by a reduced muscular mass for changes in metabolism and by a status of resistance to $\mathrm{GH}$ (201). IL-6 and TNF-a causes IGF-I resistance, directly related to the gravity of infection phase. There is a relation between GH/IGF-I axis and progression of illness (for example reduction of number of CD4 lymphoid cells, weight loss and re-allocation of adipose tissue). Moreover patients with reduced rate of CD4 helper show high levels of IGFBP-1, distinctive trait of catabolic status. Moreover TNF-a enhances levels of IGFBP-1 and its liver production. IGFBP-2 is significantly represented in the HIV patients before beginning of AIDS. Patients with AIDS-related cachexia show dramatic reduction of IGF-I, IGF-II and IGFBP-3 levels when more than $10 \%$ of body mass is lost. Replacement therapy with rhGH could increases levels of red blood cells and improves physical performance increasing enzymatic oxidative activity of skeletal muscles. rhGH replacement therapy increases IGF-I levels and is responsible for an higher muscular oxidative activity in AIDS-related cachexia. In this respect $\mathrm{GH}$ could be a new approach to improve clinical status in patients with HIV infection $(202,203)$. Also the various processes involved in HIV lipodystrophy result in the suppression of pituitary GH production. The GHRH analog Tesamorelin is the only treatment wich is FDA approved for reduction excess abdominal fat in HIV lipodystrophy (204).

\section{References}

1. Ojeda SR, McCann SM. The anterior pituitary and hypothalamus. In: Textbook of Endocrine Physiology 2000 4th edition. Griffin JE and Ojeda SR Eds. Oxford University Press.

2. Jaffe CA, Ocampo-Lim B, Guo W, et al. Regulatory mechanisms of growth hormone secretion are sexually dimorphic. J Clin Invest 1998; 102:153-164.

3. Muller EE, Locatelli V, Cocchi D. Neuroendocrine control of growth hormone secretion. Physiol Rev 1999; 75:5111-5607.

4. Carrel AL, Allen DB. Effects of growth hormone on body composition and bone metabolism. Endocrine 2000; 12(2):163-172.

5. Leung DW, Spencer SA, Cachianes G, Hammonds RG, Collins C, Henzel WJ, Barnard R, Waters MJ, Wood WI. Growth hormone receptor and serum binding protein: purification, cloning and expression. Nature 1987; 330(6148):537-543.

6. Rosenfeld RG. Molecular mechanisms of IGF-I deficiency. Horm Res 2006; 65 Suppl 1:15-20.

7. Clemmons DR. Modifying IGF1 activity: an approach to treat endocrine disorders, atherosclerosis and cancer. Nat Rev Drug Discov 2007; 6:821-833.

8. Lupu F, Terwilliger JD, Lee K, Segre GV, Efstratiadis A. Roles of growth hormone and insulin-like growth factor 1 in mouse postnatal growth. Dev Biol 2001; 229:141-162.

9. Kaplan SA, Cohen P. The somatomedin hypothesis 2007: 50 years later. J Clin Endocrinol Metab 2007; 92:4529-4535.

10. Vincent AM, Feldman EL. Control of cell survival by IGF signaling pathways. Growth Horm IGF Res 2002; 12:193-197.

11. Le Roith D, Bondy C, Yakar S, Liu JL, Butler A. The somatomedin hypothesis: 2001. Endocr Rev 2001; 22:53-74. 
12. Abuzzahab MJ, Schneider A, Goddard A. Intrauterine Growth Retardation (IUGR) Study Group. IGF-I receptor mutations resulting in intrauterine and postnatal growth retardation. N Engl J Med 2003; 349:2211-2222.

13. Rosenzweig SA. What's new in the IGF-binding proteins? Growth Horm IGF Res 2004; 14:329-336.

14. Phillips LS, Pao CI, Villafuerte BC. Molecular regulation of insulin-like growth factor-I and its principal binding protein, IGFBP-3. Prog Nucleic Acid Res Mol Biol 1998; 60:195-265.

15. Olivecrona $H$, Hilding $A$, Ekström $C$, Barle $H$, Nyberg B, Möller C, Delhanty PJ, Baxter RC, Angelin B, Ekström TJ, Tally M. Acute and short-term effects of growth hormone on insulin-like growth factors and their binding proteins: serum levels and hepatic messenger ribonucleic acid responses in humans. J Clin Endocrinol Metab 1999; 84: 553-60.

16. Jogie-Brahim S, Feldman D, Oh Y. Unraveling insulin-like growth factor binding protein-3 actions in human disease. Endocr Rev 2009; 30:417-737.

17. Hwa V, Oh Y, Rosenfeld RG. The insulin-like growth factor-binding protein (IGFBP) superfamily. Endocr Rev 1999; 20:761-787.

18. Wheatcroft SB, Kearney MT. IGF-dependent and IGF-independent actions of IGF-binding protein-1 and -2: implications for metabolic homeostasis. Trends Endocrinol Metab 2009; 20:153-162.

19. Ezzat VA, Duncan ER, Wheatcroft SB, Kearney MT. The role of IGF-I and its binding proteins in the development of type 2 diabetes and cardiovascular disease. Diabetes Obes Metab 2008; 10:198-211.

20. Ruan W, Lai M. Insulin-like growth factor binding protein: a possible marker for the metabolic syndrome? Acta Diabetol 2010; 47: 5-14.

21. Minuto F, Palermo C, Arvigo M, Barreca AM. The IGF system and bone. J Endocrinol Invest. 2005; 28(8 Suppl):8-10.

22. Canalis E. Growth factor control of bone mass. J Cell Biochem 2009; 108:769-77.

23. Foulstone E, Prince S, Zaccheo O, Burns JL, Harper J, Jacobs C, Church D, Hassan AB. Insulin-like growth factor ligands, receptors, and binding proteins in cancer. J Pathol 2005; 205:145-153.

24. Pollak M. Insulin and insulin-like growth factor signalling in neoplasia. Nat Rev Cancer 2008; 8:915928.

25. Price AJ, Allen NE, Appleby PN, Crowe FL, Travis RC, Tipper SJ et al. Insulin-like growth factor-I concentration and risk of prostate cancer: results from the European Prospective Investigation into Cancer and Nutrition. Cancer Epidemiol Biomarkers Prev 2012; 21(9):1531-1541.

26. Renehan AG, Zwahlen M, Minder C, O'Dwyer ST, Shalet SM, Egger M. Insulin-like growth factor (IGF)I, IGF binding protein-3, and cancer risk: systematic review and meta-regression analysis. Lancet 2004; 363:1346-1353.

27. Perks CM, Holly JM. IGF binding proteins (IGFBPs) and regulation of breast cancer biology. J Mammary Gland Biol Neoplasia 2008; 13:455-469.

28. Neuhouser ML, Platz EA, Till C, Tangen CM, Good- man PJ et al. Insulin-like growth factors and insulinlike growth factor-binding protein and prostate cancer risk: results from the prostate cancer prevention trial. Cancer Prev Res (Phila) 2013; 6(2):91-99.

29. Longo VD, Finch CE. Evolutionary medicine: from dwarf model systems to healthy centenarians? Science 2003; 299:1342-1346.

30. Fontana L, Partridge L, Longo VD. Extending healthy life span-from yeast to humans. Science 2010; 328:321-326.

31. Mari D. Role of the IGF/insulin system in longevity. Minerva endocrinol 2011; 36(3):181-185.

32. Junnila RK, List EO, Berryman DE, Murrey JW, Kopchick JJ. The GH/IGF-1 axis in ageing and longevity. Nat Rev Endocrinol 2013. Doi: 10. 1038/nrendo.2013.67.

33. Tatar M, Kopelman A, Epstein D, Tu MP, Yin CM, Garofano RS. A mutant drosophila insulin receptor homolog that extends lifespan and impairs neuroendocrine function. Science 2001; 292:107-110.

34. Holzenberger M, Dupont J, Ducos B, et al. IGF-1 receptor regulates lifespan and resistance to oxidative stress in mice. Nature 2003; 421:182-187.

35. Berryman DE, Christiansen JS, Johannsson G, Thorner MO, Kopchick JJ. Role of the GH/IGF-1 axis in lifespan and healthspan: lessons from animal models. Growth Horm IGF Res 2008; 18:455-471.

36. Bonafe M, Barbieri M, Marchegiani F, et al. Polymorphic variants of insulin-like growth factor I (IGF-I) receptor and phosphoinositide 3-kinase genes affect IGF-I plasma levels and human longevity: cues for an evolutionarily conserved mechanism of lifespan control. J Clin Endocrinol Metab 2003; 88:3299-3304.

37. van Heemst D, Beekman M, Mooijaart SP, et al. Reduced insulin/IGF-1 signalling and human longevity. Aging Cell 2005; 4:79-85.

38. Suh Y, Atzmon G, Cho MO, et al. Functionally significant insulin-like growth factor I receptor mutations in centenarians. Proc Natl Acad Sci USA 2008; 105:3438-3442.

39. Rowlands MA, Gunnell D, Harris R, Vatten LJ, Holly JM, Martin RM. Circulating insulin-like growth factor peptides and prostate cancer risk: a systematic review and meta-analysis. Int J Cancer 2009; 124: 2416-2429.

40. Endogenous Hormones and Breast Cancer Collaborative Group, Key TJ, Appleby PN, Reeves GK, Roddam AW. Insulin-like growth factor 1 (IGF1), IGF binding protein 3 (IGFBP3), and breast cancer risk: pooled individual data analysis of 17 prospective studies. Lancet Oncol 2010; 11:530-542.

41. Major JM, Laughlin GA, Kritz-Silverstein D, Wingard DL, Barrett-Connor E. Insulin-Like Growth Factor-I and Cancer Mortality in Older Men. J Clin Endocrinol Metab 2010; 95:1054-1059.

42. Janssen JA, Stolk RP, Pols HA, Grobbee DE, Lamberts SW. Serum total IGF-I, free IGF-I, and IGFBP1 levels in an elderly population: relation to cardiovascular risk factors and disease. Arterioscler Thromb Vasc Biol 1998; 18:277-282.

43. Johnsen SP, Hundborg HH, Sørensen HT, et al. Insulin-like growth factor (IGF) I, -II, and IGF binding 
protein-3 and risk of ischemic stroke. $\mathrm{J}$ Clin Endocrinol Metab 2005; 90:5937-5941.

44. Juul A, Scheike T, Davidsen M, Gyllenborg J, Jørgensen T. Low serum insulin-like growth factor I is associated with increased risk of ischemic heart disease: a population-based case-control study. Circulation 2002; 106:939-944.

45. Paolisso G, Ammendola S, Del Buono A, et al. Serum levels of IGF-I and IGFBP-3 in healthy centenarians. J Clin Endocrinol Metab 1997; 82:2204-2209.

46. Terry DF, Wilcox MA, McCormick MA, et al. Lower allcause, cardiovascular, and cancer mortality in centenarians' offspring. J Am Geriatr Soc 2004; 52:20742076.

47. Adams ER, Nolan VG, Andersen SL, et al. Centenarian offspring: Start healthier and stay healthier. J Am Geriatr Soc 2008; 56:2089-2092.

48. Gibney J, Healy ML, Sönksen PH. The growth hormone/insulin-like growth factor axis in exercise and sport. Endocrine Reviews 2007; 28:603-624.

49. Stokes K. Growth hormone responses to sub-maximal and sprint exercise. Growth Horm IGF Res 2003; 13:225-238.

50. Wallace JD, Cuneo RC, Bidlingmaier M, et al. The response of molecular isoforms of growth hormone to acute exercise in trained adult males. J Clin Endocrinol Metab 2001; 86:200-206.

51. Weltman A, Weltman JY, Schurrer R, Evans WS, Veldhuis JD, Rogol AD. Endurance training amplifies the pulsatile release of growth hormone: effects of training intensity. J Appl Physiol 1992; 72:2188-2196.

52. Irving BA, Weltman JY, Patrie JT, et al. Effects of exercise training intensity on nocturnal growth hormone secretion in obese adults with the metabolic syndrome. J Clin Endocrinol Metab 2009; 94:19791986.

53. Frystyk J. Exercise and the growth hormone-insulinlike growth factor axis. Med Sci Sport Exerc 2010; 42:58-66.

54. Di Luigi L, Conti FG, Casini A, et al. Growth hormone and insulin-like growth factor I responses to moderate submaximal acute physical exercise in man: effects of octreotide, a somatostatin analogue administration. Int J Sports Med 1997; 18:257-263.

55. Marcell TJ, Wiswell RA, Hawkins SA, Tarpenning $\mathrm{KM}$. Age-related blunting of growth hormone secretion during exercise may not be solely due to increased somatostatin tone. Metabolism 1999; 48:665-670.

56. De Vries WR, Abdesselam SA, Schers TJ, et al. Complete inhibition of hypothalamic somatostatin activity is only partially responsible for the growth hormone response to strenuous activity. Metabolism 2002; 51:1093-1096.

57. Maas HCM, de Vries WR, Maitimu I, Bol E, Bowers CY, Koppenschaar HPF. Growth hormone responses during strenuous exercise: the role of $\mathrm{GH}$-releasing hormone and $\mathrm{GH}$ releasing peptide-2. Med Sci Sports Exerc 2000; 32:1226-1236.

58. Wideman L, Weltman JY, Patrie JT, et al. Synergy of L-arginine and GHRP-2 stimulation of growth hormone in men and women: modulation by exercise.
Am J Physiol 2000; 279(4): R1467-R1477.

59. Di Luigi L, Guidetti L, Baldari C, Romanelli F. Heredity and pituitary response to exercise-related stress in trained men. Int J Sports Med 2003; 24:551-558.

60. Widdowson WM, Gibney J. The effect of growth hormone $(\mathrm{GH})$ replacement on muscle strength in patients with GH-deficiency: a meta-analysis. Clin Endocrinol 2010; 72:787-792.

61. Di Luigi L, Guidetti L, Nordio M, Baldari C, Romanelli F. Acute effect of physical exercise on serum insulinlike grow factor-binding protein 2 and 3 in healthy men: role of exercise-linked growth hormone secretion. Int J Sports Med 2001; 22:103-110.

62. Birzniece V, Nelson AE, Ho KKY. Growth hormone and physical performance. Trends Endocrinol Metab 2011; 22(5):171-178.

63. Liu H, Bravata DM, Olkin I, et al. Systematic review: the effects of growth hormone on athletic performance. Ann Intern Med 2008; 148:747-758.

64. Birzniece V, Nelson AE, Ho KKY. Growth administration: is it safe and effective for athletic performance. Endocrinol Metab Clin N Am 2010; 39:11-23.

65. Holt RIG, Sönksen PH. Growth hormone, IGF-I and insulin and their abuse in sport. British Journal of Pharmacology 2008; 154:542-556.

66. Holt RIG. Detecting growth hormone abuse in athetes. Drug Test Analysis 2009; 1:426-433.

67. Sartorio A, Agosti F, Marazzi N, et al. Combined evaluation of resting IGF-I, N-terminal propeptide of type III procollagen (PIIINP) and C-terminal cross-linked telopeptide of type I collagen (ICTP) levels might be useful for detecting inappropriate $\mathrm{GH}$ administration in athletes: a preliminary report. Clin Endocrinol 2004; 61:487-493.

68. Di Luigi L, Rigamonti AE, Agosti F, et al. Combined evaluation of resting IGF1, N-terminal propeptide of type III procollagen and C-terminal cross-linked telopeptide of type I collagen levels might be useful for detecting inappropriate $\mathrm{GH}$ administration in female athletes. Eur J Endocrinol 2009; 160:753-758.

69. Di Luigi L, Cappa M, Casasco M, et al. Linee guida per la concessione dell'idoneità all'attività sportiva ed il monitoraggio degli atleti affetti da malattie del sistema endocrino. Med Sport 2007; 60:225-525.

70. Wagner K, Hemminki K, Försti A. The GH1/IGF-1 axis polymorphisms and their impact on breast cancer development. Breast Cancer Res Treat 2007; 104(3):233-248.

71. Fletcher O, Gibson L, Johnson N, Altmann DR, Holly JM, Ashworth A, Peto J, Silva Idos S. Polymorphisms and circulating levels in the insulin-like growth factor system and risk of breast cancer: a systematic review. Cancer Epidemiology, Biomarkers \& Prevention 2005; 14(1):2-19.

72. Rodon J, DeSantos V, Ferry RJ Jr, Kurzrock R. Early drug development of inhibitors of the insulin-like growth factor-I receptor pathway: lessons from the first clinical trials. Mol Cancer Ther 2008; 7(9):25752588.

73. Arcaro A. Targeting the insulin-like growth factor-1 receptor in human cancer. Front Pharmacol 2013; 4: 30 doi: 3389/phar. 2013.00030. 
74. Buck E. and Mulvihill M. Small molecule inhibitors of the IGF-1R/IR axis for the treatment of cancer. Expert Opin. Investig. Drugs 2011; 20(5):605-621.

75. Corsello SM, Rota CA, Putignano P, Della Casa S, Barnabei A, Migneco MG, Vangeli V, Barini A, Mandala $\mathrm{M}$, Barone $\mathrm{C}$ and Barbarino $\mathrm{A}$. Effect of acute and chronic administration of tamoxifen on $\mathrm{GH}$ response to GHRH and on IGF-I serum levels in women with breast cancer European. Journal of Endocrinology 1998; 139(3):309-313.

76. Moon HD, Simpson ME, Li CH, Evans HM. Neoplasms in rats treated with pituitary growth hormone. I. Pulmonary and lymphatic tissues. Cancer Res 1950; 14:297-308.

77. Tornell J, Rymo L, Isaksson OG. Induction of mammary adenocarcinomas in metallothionein promoterhuman growth hormone transgenic mice. Int J Cancer 1991; 49:114-117.

78. Kaulsay KK, Zhu T, Bennett W, Lee K, Lobie PE. The effects of autocrine human growth hormone (hGH) on human mammary carcinoma cell behavior are mediated via the hGH receptor. Endocrinology 2001; 142:767-777.

79. Chopin LK, Veveris-Lowe TL, Philipps AF, Herington AC. Co-expression of $\mathrm{GH}$ and GHR isoforms in prostate cancer cell lines. Growth Horm IGF Res 2002; 12:126-136.

80. Murphy LJ, Bell GI, Friesen HG Growth hormone stimulates sequential induction of c-myc and insulinlike growth factor I expression in vivo. Endocrinology 1987; 120:1806-1812.

81. Holly JMP, Gunnell DJ, Davey Smith G Growth hormone, IGF-I and cancer. Less intervention to avoid cancer? More intervention to prevent cancer? J Endocrinol 1999; 162:321-330.

82. Baserga $R$. The contradictions of the insulin-like growth factor1 receptor. Oncogene 2000; 19:55745581.

83. Khandwala HM, McCutcheon IE, Flyvbjerg A, Friend $\mathrm{KE}$. The effects of insulin-like growth factors on tumorigenesis and neoplastic growth. Endocr Rev 2000; 21:215-244.

84. Liu X, Lin CS, Spencer EM, Lue TF. Insulin-like growth factor-I promotes proliferation and migration of cavernous smooth muscle cells. Biochem Biophys Res Commun 2001; 280:1307-1315.

85. Wu Y, Yakar S, Zhao L, Hennighausen L, LeRoith D. Circulating insulin-like growth factor-I levels regulate colon cancer growth and metastasis. Cancer Res 2002; 62:1030-1035.

86. Bustin SA, Dorudi S, Phillips SM, Feakins RM, Jenkins PJ. Local expression of insulin-like growth factor$\mathrm{I}$ affects angiogenesis in colorectal cancer. Tumour Biol 2002; 23:130-138.

87. Weber MM, Fottner C, Liu SB, Jung MC, Engelhardt D, Baretton GB. Overexpression of the insulin-like growth factor I receptor in human colon. Cancer 2002; 95:2086-2095.

88. Sachdev D, Yee D. The IGF system and breast cancer. Endocr Rel Cancer 2001; 8:197-209.

89. Bohlke K, Cramer DW, Trichopoulos D, Mantzoros CS. Insulin-like growth factor-I in relation to pre- menopausal ductal carcinoma in situ of the breast. Epidemiology 1998; 9:570-573.

90. Wolk A, Mantzoros CS, Andersson SO, Bergstrom R, Signorello LB, Lagiou P, Adami HO, Trichopoulos D. Insulin-like growth factor 1 and prostate cancer risk: a population-based, casecontrol study. J Natl Cancer Inst 1998; 90: 911-915.

91. Chan JM, Stampfer MJ, Giovannucci E, Gann PH, Ma J, Wilkinson P, Hennekens $\mathrm{CH}$, Pollak M. Plasma insulin-like growth factor-I and prostate cancer risk: a prospective study. Science 1998; 279:563-566.

92. Hankinson SE, Willett WC, Colditz GA, Hunter DJ, Michaoud DS, Deroo B, Rosner B, Speizer FE, Pollak M. Circulating concentrations of insulin-like growth factor-I and risk of breast cancer. Lancet 1998; 351:1393-1396.

93. Ma J, Pollak MN, Giovannucci E, Chan JM, Tao Y, Hennekens $\mathrm{CH}$, Stampfer MJ. Prospective study of colorectal cancer risk in men and plasma levels of insulin-like growth factor (IGF)-I and IGF-binding protein-3. J Natl Cancer Inst 1999; 91:620-625.

94. Manni A. Endocrine therapy of breast and prostate cancer. Endocrinol Metab Clin North Am 1989; 18: 569-592.

95. Schally AV, Comaru-Schalli AM, Nagy A, Kovacs M, Szepeshazi K, Plonowski A, Varga JL, Halmos G. Hypothalamic hormones and cancer. Front Neuroendocrinol 2001; 22:248-291.

96. Pollak MN, Polychronakos C, Guyda H. Somatostatin analogue SMS 201-995 reduces serum IGF-I levels in patients with neoplasms potentially dependent on IGF-I. Anticancer Res 1989; 9:889-891.

97. Dy DY, Whitehead RH, Morris DL. SMS 201.995 inhibits in vitro and in vivo growth of human colon cancer. Cancer Res 1992; 52:917-923.

98. Reiss K, Kajstura J, Zhang X, et al. Acute myocardial infarction leads to upregulation of the IGF-1 autocrine system, DNA replication, and nuclear mitotic division in the remaining viable cardiac myocytes. Exp Cell Res 1994; 213:463-472.

99. Urbanek K, Rota M, Cascapera S, et al. Cardiac stem cells possess growth factor-receptor systems that after activation regenerate the infarcted myocardium, improving ventricular function and longterm survival. Circ Res 2005; 97:663-673.

100. Haider HKH, Jiang S, Idris NM, Ashraf M. IGF-1-overexpressing mesenchymal stem cells accelerate bone marrow stem cell mobilization via paracrine activation of SDF-1alpha/CXCR4 signaling to promote myocardial repair. Circ Res 2008; 103:1300-1308.

101. Thum T, Fleissner F, Klink I, et al. Growth hormone treatment improves markers of systemic nitric oxide bioavailability via insulin-like growth factor-I. J Clin Endocrinol Metab 2007; 92:4172-4179.

102. Colao A, Ferone D, Marzullo P, Lombardi G. Systemic complications of acromegaly: epidemiology, pathogenesis, and management. Endocr Rev 2004; 25:102-152.

103. Colao A. The GH-IGF-I axis and the cardiovascular system: clinical implications. Clin Endocrinol (Oxf) 2008; 69:347-358.

104.Auriemma RS, Pivonello R, De Martino MC, Cudemo 
G, Grasso LF, Galdiero M, Perone Y, Colao A. Treatment with $\mathrm{GH}$ receptor antagonist in acromegaly: effect on cardiac arrhythmias. Eur J Endocrinol 2012; 168(1):15-22.

105. Colao A, Marzullo P, Di Somma C, Lombardi G. Growth hormone and the heart. Clin Endocrinol (Oxf) 2001; 54:137-154.

106. Colao A, Di Somma C, Cuocolo A, et al. The severity of growth hormone deficiency correlates with the severity of cardiac impairment in 100 adult patients with hypopituitarism: an observational, case-control study. J Clin Endocrinol Metab 2004; 89:5998-6004

107. Feldt-Rasmussen U, Abs R, Bengtsson BA, et al. Growth hormone deficiency and replacement in hypopituitary patients previously treated for acromegaly or Cushing's disease. Eur J Endocrinol 2002; 146: 67-74.

108. Marzullo P, Marcassa C, Campini R, et al. The impact of growth hormone/insulin-like growth factor-I axis and nocturnal breathing disorders on cardiovascular features of adult patients with Prader-Willi syndrome. J Clin Endocrinol Metab 2005; 90:5639-5646.

109. Maison P, Chanson P. Cardiac effects of growth hormone in adults with growth hormone deficiency: a meta-analysis. Circulation 2003; 108:2648-2652.

110. Laughlin GA, Barrett-Connor E, Criqui MH, Kritz-Silverstein $D$. The prospective association of serum insulin-like growth factor I (IGF-I) and IGF-binding protein-1 levels with all cause and cardiovascular disease mortality in older adults: the Rancho Bernardo Study. J Clin Endocrinol Metab 2004; 89:114-120.

111. Brugts MP, van den Beld AW, Hofland LJ, et al. Low circulating insulin-like growth factor I bioactivity in elderly men is associated with increased mortality. J Clin Endocrinol Metab 2008; 93:2515-2522.

112. Saydah S, Graubard B, Ballard-Barbash R, Berrigan D. Insulin-like growth factors and subsequent risk of mortality in the United States. Am J Epidemiol 2007; 166:518-526.

113. Andreassen M, Raymond I, Kistorp C, Hildebrandt P, Faber J, Kristensen LØ. IGF1 as predictor of all cause mortality and cardiovascular disease in an elderly population. Eur J Endocrinol 2009; 160:25-31.

114. van Bunderen CC, van Nieuwpoort IC, van Schoor NM, Deeg DJ, Lips P, Drent ML. The association of serum insulin-like growth factor-I with mortality, cardiovascular disease, and cancer in the elderly: a population-based study. J Clin Endocrinol Metab 2010; 95:4616-4624.

115. Fazio S, Sabatini D, Capaldo B, et al. A preliminary study of growth hormone in the treatment of dilated cardiomyopathy. New Engl J Med 1996; 334:809814.

116. Le Corvoisier P, Hittinger L, Chanson P, Montagne O, Macquin-Mavier I, Maison P. Cardiac effects of growth hormone treatment in chronic heart failure: A meta-analysis. J Clin Endocrinol Metab 2007; 92:180-185.

117. Isgaard J, Bergh C-H, Caidahl K, Lomsky M, Hjalmarson $\AA$, Bengtsson B-Å. A placebo-controlled study of growth hormone in patients with congestive heart fail- ure. Eur Heart J 1998; 19:1704-1711.

118. Arcopinto M, Bobbio E, Bossone E, Perrone-Filardi P, Napoli R, Saccà L, Cittadini A. The relevance of endocrine and metabolic disorders in heart failure: from pathophysiology to therapeutic approach. Endocr Metab Immune Disord Drug Targets 2013.

119. Russell-Jones DL, Bates AT, Umpleby AM, et al. A comparison of the effects of IGF-I and insulin on glucose metabolism, fat metabolism and the cardiovascular system in normal human volunteers. Eur J Clin Invest 1995; 25:403-411.

120.Donath MY, Froesch ER, Zapf J. Insulin-like growth factor I and cardiac performance in heart failure. Growth Horm IGF Res 1998; 8(Suppl B):167-170.

121. Nagaya N, Moriya J, Yasumura Y, et al. Effects of ghrelin administration on left ventricular function, exercise capacity, and muscle wasting in patients with chronic heart failure. Circulation 2004; 110:36743679.

122. Mottillo S, Filion KB, Genest J, et al. The metabolic syndrome and cardiovascular risk a systematic review and meta-analysis. J Am Coll Cardiol 2010; 56(14):1113-1132.

123. Chrysant SG. Stopping the cardiovascular disease continuum: focus on prevention. World $\mathrm{J}$ Cardiol 2010; 26:43-49.

124. McCallum RW, Petrie JR, Dominiczak AF, Connell JMC. Growth hormone deficiency and vascular risk. Clin Endocrinol (Oxf) 2002; 57:11-24.

125. Di Somma C, Pivonello R, Pizza G, et al. Prevalence of the metabolic syndrome in moderately-severely obese subjetcs with and without growth hormone deficiency. J Endocrinol Invest 2010; 33:171-177.

126. Sandhu MS, Heald AH, Gibson JM, et al. Circulating concentrations of insulin-like growth factor $-I$ and development of glucose intolerance: a prospective observational study. Lancet 2002; 359(9319):17401745.

127. Schneider HJ, Friedrich N, Klotsche J, et al. Prediction of incident diabetes mellitus by baseline IGF1 levels. Eur J Endocrinol 2011; 164:223-229.

128. Schneider HJ, Klotsche J, Saller B, et al. Associations of age-dependent IGF-I SDS with cardiovascular diseases and risk conditions: cross-sectional study in 6773 primary care patients. Eur J Endocrinol 2008; 158:153-161.

129. Maison P, Griffin S, Nicoue-Beglah M, et al. Impact of growth hormone $(\mathrm{GH})$ treatment on cardiovascular risk factors in $\mathrm{GH}$-deficient adults: a metaanalysis of blinded, randomized, placebo-controllated trials. J Clin Endocrinol Metab 2004; 89:2192-2129.

130. Attanasio AF, Mo D, Erfurth EM, et al. Prevalence of metabolic syndrome in adult hypopituitary growth hormone (GH)-deficient patients before and after GH replacement. J Clin Endocrinol Metab 2010; 95:74-81.

131. Moses AC, Young SC, Morrow LA, O’Brien M, Clemmons DR. Recombinant human insulin-like growth factor I increases insulin sensitivity and improves glycemic control in type II diabetes. Diabetes 1996; 45:91-100.

132. Carroll PV, Christ ER, Umpleby AM. IGF-I treatment 
in adults with type 1 diabetes: effects on glucose and protein metabolism in the fasting state and during a hyperinsulinemic-euglycemic amino acid clamp. Diabetes 2000, 49 : 789-96.

133. Clemmons DR, Moses AC, McKay MJ, et al. The combination of insulin-like growth factor I and insulin-like growth factor-binding protein-3 reduces insulin requirements in insulin-dependent type 1 diabetes: evidence for in vivo biological activity. J Clin Endocrinol Metab 2000, 85 : 1518-1524.

134. Sherlock M, Ayuk J, Tomlinson JW et al. Mortality in patients with pituitary disease. Endocrine Reviews 2010; 31:301-342.

135. Colao A, Baldelli R, Marzullo P, et al. Systemic hypertension and impaired glucose tolerance are independently correlated to the severity of the acromegalic cardiomyopathy. J Clin Endocrinol Metab 2000; 85:193-199.

136. Berg C, Petersenn S, Lahner H, et al. Cardiovascular risk factors in patients with uncontrolled and long term acromegaly: comparison with matched data from the general population and the effect of disease control. J Clin Endocrinol Metab 2010; 95:3648-3656.

137. Mazziotti G, Floriani I, Bonadonna S, et al. Effects of somatostatin analogs on glucose homeostasis: a metaanalysis of acromegaly studies. J Clin Endocrinol Metab 2009; 94:1500-1508.

138. Colao A, Auriemma RS, Galdiero M, et al. Effects of initial therapy for five years with somatostatin analogs for acromegaly on growth hormone and insulin -like growth factor-I levels, tumor shrinkage, and cardiovascular disease: a prospective study. J Clin Endocrinol Metab 2009; 94:528-537.

139. Couture E, Bongard V, Maiza JC, Bennet A, Caront I. Glucose status in patients with acromegaly receiving primary treatment with the somatostatin analog lanreotide. Pituitary 2012; 15(4):518-525.

140. Petersenn S, Schopohl J, Barkan A, et al. Pasireotide (SOM 230) demonstrates efficacy and safety in patients with acromegaly: a randomized multicenter, phase II trial. J Clin Endocrinol Metab 2010; 95:27812789.

141. Colao A, Auriemma RS, Savastano S, et al. Glucose tolerance and somatostatin analog treatment in acromegaly: a 12-month study. J Clin Endocrinol Metab 2009; 94:2907-2914.

142. Urbani C, Sardella C, Calevro A, Rossi G, Scattina C,Lombardi M, Lupi I, Manetti L, Martino E, Bogazzi F. Effects of medical therapies for acromegaly on glucose metabolism. Eur J Endocrinol 2013, May 9.

143. Lindberg-Larsen R, Moller N, Schmitz O, et al. The impact of pegvisomant treatment on substrate metabolism and insulin sensitivity in patients with acromegaly. J Clin Endocrinol Metab 2007; 92:17241728.

144. Higham CE, Rowles S, Russell-Jones D, et al. Pegvisomant improves insulin sensitivity and reduces overnight free fatty acid concentrations in patients with acromegaly. J Clin Endocrinol Metab 2009; 94: 2459-2463.

145. Moller L, Norrelund H, Jessen N. Impact of growth hormone receptor blockade on substrate metabolism during fasting in healthy subjects. J Clin Endocrinol Metab 2009; 94:4524-4532.

146. Giavoli C, Ferrante E, Profka E, et al. Influence of the d3GH receptor polymorphism on the metabolic and biochemical phenotype of GH-deficient adults at baseline and during short- and long-term recombinant human $\mathrm{GH}$ replacement therapy. Eur J Endocrinol 2010; 163:361-368.

147. Mercado M, Gonzales B, Sandoval C, et al. Clinical and biochemical impact of the $\mathrm{d} 3(\mathrm{fl})$ growth hormone receptor genotype in acromegaly. J Clin Endocrinol Metab 2008; 93:3411-3415.

148. Montefusco L, Filopanti M, Ronchi C, et al. D3-growth hormone receptor polymorphism in acromegaly: effects on metabolic phenotype. Clin. Endocrinol 2010; 72:661-667.

149.Baldelli R, Battista C, Leonetti F, et al. Glucose homeostasis in acromegaly: effects of long-acting somatostatin analogues treatment. Clin Endocrinol 2003; 59:492-499.

150.Resmini E, Minuto F, Colao A, Ferone D. Secondary diabetes associated with principal endocrinopathies: the impact of new treatment modalities. Acta Diabetol 2009; 46:85-95.

151.Barkan AL, Burman P, Clemmons DR. Glucose homeostasis and safety in patients with acromegaly converted from long-acting octreotide to pegvisomant. J Clin Endocrinol Metab 2005; 90:5684-5691.

152.Addison ML, Rissman EF. Sexual dimorphism of growth hormone in the hypothalamus: regulation by estradiol. Endocrinology 2012; 153(4):1898-97

153.Zachmann M. Interrelations between growth hormone and sex hormones- physiology and therapeutic consequences. Hormone Research 1992; 38:1-8.

154.Franks S. Growth hormone and ovarian function. Baillieres Clinicalv Endocrinology and Metabolism 1998; 12:331-340.

155. Kerry LH and Harvey S. Growth Hormone - Roles in Male Reproduction. Review Endocrine 2000; 13:243250.

156. Lobie PE, Breipohl W, Garcia-Aragon J and Waters MJ. Cellular localization of the growth hormone receptor/binding protein in the male and female reproductive system. Endocrinology 1990; 126:2214-2221.

157. Carlsson B, Bergh C, Bentham J, Olsson JH, Norman MR, Billig $\mathrm{H}$, et al. Expression of functional growth hormone receptors in human granulosa cells. Human Reproduction 1992; 7:1205-1209.

158.Schwarzler P, Untergasser G, Hermann M, Dirnhofer S, Abendstein B, Madersbacher S and Berger P. Selective growth hormone/placental lactogen gene transcription and hormone production in preand postmenopausal human ovaries. Journal of Clinical Endocrinology and Metabolism 1997; 82:3337-3341.

159. Untergasser G, Kranewitter W, Schwarzler P, Madersbacher S, Dirhnofer S and Berger P. Organ-specific pattern of the human growth hormone/placental lactogen gene cluster in the testis. Molecular and Cellular Endocrinology 1997; 130:53-60.

160. Tanner JM and Whitehouse RH. A note on the bone age at which patients with true isolated growth hor- 
mone deficiency enter puberty. J Clin Endocrinol Metab 1975; 41:788-790.

161. Laron Z, Sarel R. Penis and testicular size in patients with growth hormone insufficiency. Acta Endocrinol 1970; 63(4):625-633.

162. Laron Z, Klinger B. Effect of insulin-like growth factor-1 treatment on serum androgens and testicular and penile size in males with Laron syndrome (primary growth hormone resistance). Eur J End 1998; 138:176-180.

163. Reiter E, Hunnuy B, Bryninx M, Cornet A, Klug M, McNamara M, et al. Effects of pituitary hormones on the prostate. Prostate 1999; 38:159-165.

164. Adashi EY, et al. Somatomedin-C enhances induction of luteinizing hormone receptors by follicle-stimulating hormone in cultured rat granulosa cells. Endocrinology 1985; 116:2363-2375.

165. Adashi EY, Resnick CE, Svoboda ME, Van Wyk JJ. Somatomedin-C synergises with follicle-stimulating hormone in the acquisition of progestin biosynthetic capacity by cultured rat granulosa cells. Endocrinology 1985; 116:2135-2142.

166. Ovesen P. Synergistic effects of growth hormone and insulin-like growth factor-I on differentiation and replication of cultured human luteinized granulosa cells. Acta Obstetrica and Gynecologica Scandinavia 1998; 77:487-491.

167. Yoshimura $Y$, Nakamura $Y$, Koyama N, Iwashita M, Adachi T, Takeda Y. Effects of growth hormone on follicle growth, oocyte maturation, and ovarian steroidogenesis. Fertility and Sterility 1993; 59: 917-923.

168. Yoshimura Y, Iwashita M, Karube M, Oda T, Akiba M, Shiokawa S, et al. Growth hormone stimulates follicular development by stimulating ovarian production of insulinlikegrowth factor-I. Endocrinology 1994; 135:887-894.

169. Shimonovitz S, Zacut D, Benchetrit A, Ron M. Growth hormone status in patients with maturation arrest of spermatogenesis. Hum Reprod 1993; 8:919-921.

170. Radicioni A, Paris E, Dondero F, Bonifacio V, Isidori A. Recombinant-growth hormone therapy in infertile men with idiopathic oligozoospermia. Acta Eur Fertil 1994; 25:311-317.

171. Shoham Z, et al. Conway GS, Ostergaard H, Lahlou $\mathrm{N}$, Bouchard P, Jacobs HS. Cotreatment with growth hormone for induction of spermatogenesis in patients with hypogonadotropic hypogonadism. Fertil Steril 1992, 57:1044-1051.

172. Zalel Y, Draysen E, Goldschmit R, Zadik Z, Shoham Z. A prospective pilot study of co-treatment with growth hormone and gonadotropins for improving spermatogenesis in normogonadotropic patients with severe oligoteratoasthenospermia. Gynecol Endocrinol 1996; 10(1):23-28.

173. Kanzaki M and Morris PL. Growth hormone regulates steroidogenic acute regulatory protein expression and steroidogenesis in Leydig cell progenitors. Endocrinology 1999; 140:1681-1686.

174. de Boer JA, Schoemaker J, van der Veen EA. Impaired reproductive function in women treated for growth hormone deficiency during childhood. Clinical Endocrinology 1997; 46:681-689.
175. Homburg R and Farhi J. Growth hormone and reproduction. Current Opinion in Obstetrics and Gynecology 1995; 7:220-223.

176. Shoham Z, Homburg R, Owen EJ, Conway GS, Ostergaard $\mathrm{H}$, Jacobs $\mathrm{HS}$. The role of treatment with growth hormone in infertile patients. Baillieres Clinical Obstetrics and Gynecology 1992; 6(2):267-281.

177. Varadaraj C, Denise Z, Andrzej B. The consequences of altered somatotropic system on reproduction. Biol Reprod 2004; 71:17-27.

178. Ogilvy-Stuart AL, Shalet SM. Commentary - growth hormone and Puberty. J Endocrinol 1992; 135: 405406.

179. Cannata D, Vijayakumar A, Fierz Y, LeRoith D. The GH/IGF-1 axis in growth and development: new insights derived from animal models. Adv Pediatr 2010; 57(1):331-351.

180. Giustina A, Mazziotti G, Canalis E. Growth hormone, insulin-like growth factors, and the skeleton. Endocr Rev 2008; 29(5):535-559.

181.Lombardi G, Di Somma C, Vuolo L, Guerra E, Scarano E, Colao A. Role of IGF-I on PTH effects on bone. J Endocrinol Invest 2010, 33(7 Suppl): 22-6. Review.

182. Jørgensen AP, Fougner KJ, Ueland T, Gudmundsen O, Burman P, Schreiner T, Bollerslev J. Favorable long-term effects of growth hormone replacement therapy on quality of life, bone metabolism, body composition and lipid levels in patients with adult-onset growth hormone deficiency. Growth Horm IGF Res 2011; $21(2): 69-75$.

183. Colao A, Di Somma C, Pivonello R, Loche S, Aimaretti G, Cerbone G, Faggiano A, Corneli G, Ghigo E, Lombardi G. Bone loss is correlated to the severity of growth hormone deficiency in adult patients with hypopituitarism. J Clin Endocrinol Metab 1999; 84(6):1919-1924.

184.Elbornsson M, Götherström G, Franco C, Bengtsson BÅ, Johannsson G, Svensson J. Effects of 3year $\mathrm{GH}$ replacement therapy on bone mineral density in younger and elderly adults with adult-onset GH deficiency. Eur J Endocrinol 2012; 166(2):181189.

185. Rota F, Savanelli MC, Tauchmanova L, Savastano S, Lombardi G, Colao A, Di Somma C. Bone density and turnover in young adult patients with growth hormone deficiency after 2-year growth hormone replacement according with gender. J Endocrinol Invest 2008; 31(2):94-102.

186. Bonadonna S, Mazziotti G, Nuzzo M, Bianchi A, Fusco A, De Marinis L, Giustina A. Increased prevalence of radiological spinal deformities in active acromegaly: a cross-sectional study in postmenopausal women. J Bone Miner Res 2005; 20:1837-1844.

187. Madeira M, Neto LV, Torres CH, de Mendonça LM, Gadelha MR, de Farias ML. Vertebral fracture assessment in acromegaly. J Clin Densitom 2013; 16(2):238-243.

188. Iranmanesh A, Lizarralde G, Veldhuis JD. Age and relative adiposity are specific negative determinants of the frequency and amplitude of growth hormone 
(GH) secretory bursts and the half-life of endogenous $\mathrm{GH}$ in healthy men. J Clin Endocrinol Metab 1991; 73(5):1081-1088.

189. Cordido F, Peñalva A, Dieguez C, Casanueva FF. Massive growth hormone $(\mathrm{GH})$ discharge in obese subjects after the combined administration of GH-releasing hormone and GHRP-6: evidence for a marked somatotroph secretory capability in obesity. J Clin Endocrinol Metab 1993; 76(4):819-823.

190. Frystyk J, Brick DJ, Gerweck AV, Utz AL, Miller KK. Bioactive insulin-like growth factor-I in obesity. J Clin Endocrinol Metab 2009; 94(8):3093-3097.

191. Cornford AS, Barkan AL, Horowitz JF. Rapid suppression of growth hormone concentration by overeating: potential mediation by hyperinsulinemia. J Clin Endocrinol Metab 2011; 96(3):824-830.

192. Succurro E, Andreozzi F, Sciaqua A, Hribal ML, Perticone F, Sesti G. Reciprocal association of plasma IGF-1 and interleukin-6 levels with cardiometabolic risk factors in nondiabetic subjects. Diabetes Care. 2008; 31(9):1886-1888.

193. Luque RM, Kineman RD. Impact of obesity on the growth hormone axis: evidence for a direct inhibitory effect of hyperinsulinemia on pituitary function. Endocrinology 2006; 147(6):2754-2763.

194. Rasmussen MH, Hvidberg A, Juul A, et al. Massive weight loss restores 24-hour growth hormone release profiles and serum insulin-like growth factor-I levels in obese subjects. J Clin Endocrinol Metab 1995; 80(4):1407-1415.

195. De Marinis L, Bianchi A, Mancini A, et al. Growth hormone secretion and leptin in morbid obesity before and after biliopancreatic diversion: relationships with insulin and body composition. J Clin Endocrinol Metab 2004; 89(1):174-180.

196. Scacchi M, Orsini F, Cattaneo A, et al. The diagno- sis of $\mathrm{GH}$ deficiency in obese patients: a reappraisal with GHRH plus arginine testing after pharmacological blockade of lipolysis. Eur J Endocrinol 2010; 163(2): 201-206.

197. Rasmussen $\mathrm{MH}$. Obesity, growth hormone and weight loss. Mol Cell Endocrinol 2010; 316(2):147153.

198.Dardenne M, Smaniotto S, de Mello-Coelho V, VillaVerde DM, Savino W. Growth hormone modulates migration of developing T cells. Ann N Y Acad Sci 2009; 1153:1-5.

199. Morrhaye G, Kermani H, Legros JJ, Baron F, Beguin Y, Moutschen M, Cheynier R, Martens HJ, Geenen V. Impact of growth hormone $(\mathrm{GH})$ deficiency and $\mathrm{GH}$ replacement upon thymus function in adult patients. PLoS one 2009, 4(5): e5668.

200.Esposito JG, Thomas SG, Kingdon L, Ezzat S. Growth hormone treatment improves peripheral muscle oxygen extraction-utilization during exercise in patients with Human Immunodeficiency Virus-associated wasting: a randomized controlled trial. J Clin Endocrinol Metab 2004; 89:5124-5131.

201. Congote LF. Monitoring insulin-like growth factors in HIV infection and AIDS Clinica Chimica Acta 2005; 361(1-2):30-53.

202. Napolitano LA, Schmidt D, Gotway MB, et al. Growth hormone enhances thymic function in HIV-1-infected adults. J Clin Invest 2008; 118(3):1085-1098.

203.Spinola-Castro AM, Siviero-Miachon AA, da Silva MT, Guerra-Junior G. The use of growth hormone to treat endocrine-metabolic disturbances in acquired immunodeficiency syndrome (AIDS) patients. Arq Bras Endocrinol Metabol 2008; 52(5): 818-813.

204.Jain S, Desai N, Bhangoo A. Pathophysiology of GHRH-growth hormone-IGF-1 axis in HIVIAIDS. Rev Endocr Metab Disord 2013 May 9. 